\section{Џудит Халберстам}

\section{СИЛЕЏИИ, ЧУДАЦИИКРАЛЕВИ: ПОСТИМПЕРИЈАЛНИ МАЖЕСТВЕНОСТИ}

\author{
„Минатогодишните зборови му \\ припагаaт на минатогодишниот \\ јазик, \\ А зборовите од идната година \\ чекаат нов глас." \\ Т.С. Елиот, „Мала замаеност“ (1943)
}

Вовед

Q мојата книга Женска мажественост (Duke UP, 1998), речиси ништо немам кажано за различните доминантни и субверзивни форми на машката мажественост. Мојот отпор да се впуштам во темата за машките мажествености во мојот проект ги остава отворени прашањата за неодреденоста на терминот "мажественост" и за можните историски проблеми, бидејќи не успева да развие модел за продукција на машкоста. Сепак, во Женската мажественост тврдев дека ако она што го нарекуваме „доминантна мажественост“ се чини дека е натурализиран однос мегу мажевноста и моќта, тогаш не е многу паметно мажите да ги прашаме за контурите на неговата општествена конструкција. Машката мажественост во мојот проект фигурира како херменевтика, како пример спротивен на видовите мажественост што се чинат најинформативни за односите меѓ родовите и најпродуктивни за општествените промени.

Во овој есеј за „постимперијалната мажественост" би сакала да употребам некои парадигми што произлегуваат од моите поранешни дела, за да го проучам влијанието на другите помали модели на мажественост врз доминантните концепции на машкиот род и машкоста. ${ }^{1}$ Би сакала и дискусијата за женската мажественост да ја поставам до цела низа алтернативни мажествености во постмодер-
Judith Halberstam

\section{THUGS, GEEZERS AND KINGS: POST-IMPERIALMASCULINITIES}

"For last year's words belong to last year's language And next year's words await another voice."

T.S. Eliot, "Little Gidding" (1943)

Introduction

In my book Female Masculinity (Duke UP, 1998), I found that I had little if nothing to say about the various dominant and subversive forms taken by male masculinity. My resistance to engaging the topic of male masculinities certainly left my project open to questions about the vagueness of the term masculinity itself and possibly created historical problems by failing to develop a model of the production of manliness. However, I argued in Female Masculinity that if what we call "dominant masculinity" appears to be a naturalized relation between maleness and power, then it makes little sense to examine men for the contours of its social construction. Male masculinity figured in my project as a hermeneutic, and as a counter example to the kinds of masculinity which seem most informative about gender relations and most generative of social change.

In this essay on "post-imperial" masculinities, I would like to use some of the paradigms generated by my earlier work to examine the impact of other minority models of masculinity upon dominant conceptions of manhood and manliness.' I also want to situate the discussion of female masculinity alongside a whole array of alternative masculinities within postmodernity which, when taken.together, launch a powerful critique of mod- 
низмот кои заедно лансираат моќна критика на модернистичката, односно на она што може да се нарече империјалистичка мажественост. Тука го поставувам прашањето за тоа дали новите и скорешни претставувања на британската мажественост во филмот и литературата на денешницата можат да произведат и различни модели мажественост, модели што се занимаваат со специфичностите на работничката класа, мажественостите на црнците и на поинаквите [queer], а не само да ја апсорбираат мажественоста на помалите групи во скандалозноста на инаквоста. Ќ се движам напред-назад меѓу различните места на културната продукција во британски контекст, сите места за кои се чини дека укажуваат на современата криза на машкиот идентитет ${ }^{2}$. Почнувам со пример на империјалистичка етнографска нарација за феноменот на фудбалските хулигани во Бил Бафордовата социјална приказна Meí силешиите, а потоа се свртувам кон спротивната постимперијалистичка нарација за истиот феномен во озлогласениот шкотски роман на Ирвин Велч Trainspotting; последниот дел од мојот текст се занимава со новиот британски комичен филм за мажественоста и класните идентитети - Како од мајка родени и, на крајот, се свртувам кон изведбите на женските травестити во лондонскиот клуб "Чудаци". Сиве претстави на мажественоста на работничката класа се случуваат во 90-те години во Британија, но тие се и размислување за фасцинантната историја на британскиот народ, историја што колонијализмот и империјата ги поврзува со родовите идеологии.

Во револуционерната книга, Машкоста и цивилизацијата, Гејл Бедермен го опишува подемот на мажественоста на белците од средната класа во Америка како внимателна употреба на дискурсите за расната доминација и цивилизацијата. Таа истакнува дека боксерскиот меч меѓу црнецот Џек Џонсон и белецот Џим Џефрис, при преминот во новиот век, станува расистички натпревар на мажевност што, според неа, е пример за "многубројните начини што ги наоѓаат Американците од средната класа за да ја објаснат машката надмоќ како белечка расна доминација и обратно, белечката доминација да ја објаснат како машка моќ“3 Во прогресивната ера во Америка, бел- ernist or what can be called imperialist masculinity. I raise the question here of whether new and recent representations of British masculinity in contemporary film and literature are capable of generating different models of masculinity, models which address the specificities of working class, black and queer masculinities rather than just absorbing minority masculinity into the ignominy of otherness. I will be ranging back and forth between very different sites of cultural production in a British context all of which seem to point to a contemporary crisis in masculine identity: ${ }^{2}$ I start with an example of an imperialist ethnographic narrative about the phenomenon of the football hooligan in Bill Buford's social narrative Among the Thugs and then I turn to a post-imperialist counter-narrative about the same phenomenon in Irvine Welsh's notorious Scottish novel Trainspotting; the last part of my paper considers a recent British comic film about masculinity and class identities - The Full Monty and, finally, I turn to drag king performances in London's Club Geezer. All of these representations of working class masculinities are situated in 1990's Britain but all also reflect upon a fascinating history of British manhood, a history that links colonialism and empire to gender ideologies.

In her ground-breaking book Manliness and Civilization, Gail Bederman has described the rise of middle-class white masculinity in America as the careful deployment of discourses of racial dominance and civilization. A turn of the century boxing match between black fighter Jack Johnson and white fighter Jim Jeffries, she points out, became a racialized contest of virility which, she states, was an example of the "multitude of ways middle-class Americans found to explain male supremacy in terms of white racial dominance and conversely to explain white supremacy in terms of male power."3 White middle class men aspired to a morally sanctioned model of manhood in the Progressive Era in America while keeping at bay competing 
ците од средната класа се стремат кон етички санкциониран модел на колективитет, додека ги држат на отстојание другите форми на моќна мажественост, какви што се црнечката мажественост, агилноста на работничката класа, дури и женската мажественост како инверзивна форма (иако Бедермен не го истражува последново). Во контекст на Англија, историјата на машкоста различно се внесува преку дискурси, не само за расната доминација, туку и за британскиот колонијализам и империјата, како што би можеле да очекуваме. Натаму, при преминот во новиот век, дебатите за мажественоста во Англија барем делумно биле придвижени од општите стравови за дегенерацијата на западната цивилизација и падот на империјата и од специфичната вознемиреност поради ранливоста на мажите од владејачката класа. Судењето на Оскар Вајлд, во овој контекст, повеќе отколку боксерскиот меч, станува симбол на британската мажественост која е загрозена и е навистина фрагилна.

Како што покажа делото на историчарот Мриналини Сина, подемот на сексолошкиот дискурс за хомосексуалноста во Британија во 1890-те коинцидира со ориенталистичката категоризација на Индијците како „феминизирани". Таа во Колонијална мажественост тврди: "Една од придобивките наКолонијална мажественост е да покаже дека претставата од доцниот деветнаесетти век за англиската/британската мажественост или за бенгалската/ индиската феминизираност, не може да биде разбрана од рамката на дискретните „национални“ култури; наместо тоа, тие треба да бидат разбрани преку односот што го имаат еден спрема друг и како конституенти." ${ }^{4}$ Сина корисно го истакнува и тоа дека скорашните дела за британската мажественост „не успеале да ја ословат целосната импликација за империјалната заснованост на британската мажественост" (10). „Британската“ мажественост, на крајот, никогаш не е само или дискретно британска; таа е повеќе резултат на потпорни компарации, засилувања, подмолности и преговори меѓ машките субјекти и моќните колонијални системи. ${ }^{5}$ Работата врз постимперијалните мажествености мора да ја земе предвид историјата на англиската мажественост од дваесеттиот forms of powerful masculinity in the form of black masculinity, working class virility and even (although Bederman does not explore this) female masculinity in the form of inversion. In an English context, the history of manliness has been differently inflected through discourses of not simply racial dominance but also British colonialism and empire as we might expect. Furthermore, turn of the century debates about masculinity were mobilized in England at least in part by general fears about the degeneration of Western civilization and the decline of empire, and specific anxieties about the vulnerability of ruling class masculinity. The trial of Oscar Wilde, in this context, rather than a boxing match became a symbol of a threatened and indeed fragile British masculinity.

As the work of historian Mrinalini Sinha has shown, the rise of a sexological discourse on homosexuality in Britain coincided in the 1890's with the Orientalist characterization of Indian men as "effeminate." She argues in Colonial Masculinity. "One of the contributions of Colonial Masculinity is to demonstrate that late nineteenth century notions of English/British masculinity or Bengali/lndian effeminacy cannot be understood from the framework of discrete "national" cultures; instead, they must be understood in relation to one another, and as constitutive of each other.". Sinha also usefully points out that recent work on British masculinity has "failed to address the full implication of the imperial constitution of British masculinity" (10). "British" masculinity, in the end, is never simply nor discretely British; rather it is the result of sustained comparisons, enforcements, abjections and negotiations between and among masculine subjects within colonial networks of power. ${ }^{5}$ Work on post-imperial masculinities must acknowledge the twentieth century history of English masculinity as precisely this history of overlapping national and colonial agendas; but, it also requires a shift in focus to the contemporary period where we have seen, in recent years, an efflorescence of representations of reinvigorated masculinities. These representations fall into two different categories: nar- 
век, токму како вкрстување на националните и колонијалните планови; но, таа бара и поместување на фокусот кон современиот период, каде што, во последниве години видовме процут на претстави на оживотворените мажествености. Овие претстави се двојат во две категории: нарации што ги признаваат критиките на модернизмот, а сепак произведуваат империјални мажествености и нарации што ги признаваат, ги произведуваат и ги креираат постимперијалните мажествености.

\section{1. Меѓу силеџиите: империјални мажествености}

Meŕy 1890 и 1920 во Англија, поимите за мажественоста на работничката класа и онаа на владејачката класа беа подложени на огромни поместувања и промени. Како што покажува Сет Ковен во својот есеј „Момчешки живот, национална култура и општествени реформи", категоријата „грубијан“ во овој период била трансформирана во категоријата „хулиган“, па тој пишува дека „момчешкиот живот станал пригоден стенограм за претпоставката дека однесувањето на работничката класа, адолесцентите и граѓаните неизбежно е општествен проблем". ${ }^{\text {" }}$

Додека мажественоста на работничката класа претставувала еден вид општествен проблем, друг вид проблем била хомосексуалноста; а како што сигнализира Ковен во својот есеј, растечките стравови од сексуалната перверзија создале нови облици на надзор врз односите меѓу мажите и момчињата. Новите закони што ја забранувале машката хомосексуалност биле востановени на преминот во новиот век, иако тогаш сексолошките студии се бореле да ја артикулираат природноста на хомосексуалниот инстинкт. Новите општествени, правни и медицински дефиниции на нормативните и не-нормативните машки изразувања на желбите коинцидирале и со пустошењата на Првата светска војна и со забележителниот пад на британската колонијална моќ. Големите поместувања во демографијата и имиграцијата, во националниот дискурс и во дефинициите на сексуалноста и родовите, ги извадиле на светлина различните изрази на машката мажественост на малите групи. Инверзивните сексолошки дискурси дури ratives which acknowledge critiques of modernism and yet still produce imperial masculinities and narratives which acknowledge, produce and invent post-imperial masculinities.

\section{Among the Thugs: Imperial Masculinities}

Between 1890 and 1920 in England, notions of both working class and ruling class masculinity underwent huge shifts and changes. As Seth Koven shows in an essay on "Boy Life, National Culture and Social Reform," the category of the "rough lad" during this period was transformed into the category of the "hooligan" and, he writes, "boy life became a convenient shorthand for the assumption that working class, adolescent, urban male behavior was necessarily a social problem."

While working class masculinity presented one kind of social problem, homosexual masculinity was another; and as Koven signals in his essay, growing fears of sexual perversion created new forms of surveillance of the relations between men and boys. New laws prohibiting male homosexuality were instituted at the turn of the century even as sexological studies struggled to articulate the naturalness of homosexual instinct. These new social, legal and medical definitions of normative and non-normative masculine expressions of desire coincided furthermore with the ravages of the First World War and a noticeable decline in British colonial power. Large scale shifts in demographics, in immigration, in national discourse and in sexuality and gender definitions brought to visibility diverse expressions of minority male masculinities. Sexological discourses of inversion even allowed for the possibility of non-male masculinity by attributing the cause of same-sex desire to a congenital gender disorder. Female homosexuals, therefore, were those women who felt themselves to be essentially and even physi- 
и ја допуштаат можноста за немашка мажественост, со тоа што причината за желбата спрема истиот пол му ја припишуваат на вродено родово нарушување. Оттука, женските хомосексуалци биле оние жени кои за себе сметале дека се во суштина, дури и психолошки, мажествени, а машките хомосексуалци биле оние мажи кои за себе сметале дека во суштина се женствени. Инверзивните дискурси имаат контрадикторни ефекти врз родовата идеологија: од една страна, тие ги стабилизирале машката женственост и женската мажественост како главни означувачи на хомосексуалноста, а го натурализирале хетеросексуалниот желбен модел; а од друга страна ги одвоиле женственоста од жените, а мажественоста од мажите, па допуштиле природно да се појави родова варијантност.

За време на Првата светска војна, сознанијата за сексологијата имале длабоки импликации за стотици војници кои од фронтот се вратиле боледувајќи од различни форми на исцрпувачка хистерија, а во исто време, стотици жени, или ги презеле машките работи на домашниот фронт, или барале да возат амбулантни возила на фронтот. Со оглед на тоа дека машката женственост дефинитивно била врзана со хомосексуалноста, машката хистерија била особено вознемирувачка невроза, а бидејќи женската мажественост била дефинитивно врзана со женската хомосексуалност, партиципацијата на жените во машките задолженија била причина за грижа околу влијанието на новиве задолженија врз „женскиот карактер“. Би можеле да кажеме дека импотентниот и хистеричен маж (на пример Септимус Смит во Госпоѓата Деловеј на Вирџинија Вулф, Прафрок на Т.С. Елиот и Ралф Сајн во Мимичарот на В.С. Нејпол) и мажествена жена (Стивен Гордон во Изворот на осаменоста на Редклиф Хол, Орландо на Вулф) го прогонуваат модернизмот речиси онака како што вампирите и духовите ја прогонуваат претходната генерација. Т.С. Елиот му даде единствен израз на очајот на белечката мажественост во опаѓање: „Ние сме шупливите мажи, маса без облик/ Парализирана сила, гест без движење"7, Намерата на Елиот можеби била Прафрокс и шупливите мажи да го предупредат општеството за уривачките ефекти од опагањето на традиционалните стан- ologically masculine and male homosexuals were those men who felt themselves to be essentially feminine. The discourses of inversion had contradictory effects upon gender ideology: on the one hand, they stabilized male femininity and female masculinity into the master signifiers of homosexuality and naturalized a heterosexual model of desire; on the other hand they detached femininity from women and masculinity from men and allowed for the "natural" occurrence of gender variation.

During World War 1, the insights of sexology had profound implications as hundreds of male soldiers returning from the front suffered from various forms of a debilitating hysteria and, at the same time, hundreds of women either took over masculine jobs on the home front or petitioned to drive ambulances at the front. Since male femininity had been tied so definitively to homosexuality, male hysteria was a particularly troubling neurosis and since female masculinity had been tied so definitively to female homosexuality, the participation of women in masculine occupations gave cause for concern about the impact of these new occupations on "female character." We could say that the impotent and hysterical man (Virginia Woolf's Septimus Smith in Mrs Dalloway, T.S. Eliot's Prufrock and V.S. Naipaul's Raiph Singh in Mimic Men for example) and the virile woman (Radclyffe Hall's Stephen Gordon in The Well of Loneliness, Woolf's Orlando) haunt modernism almost as vampires and ghosts had haunted an earlier generation. T.S. Eliot gave singular expression to the desperation of a white masculinity in decline: "We are the hollow men, shape without form, shade without color/Paralysed force, gesture without motion." Eliot may have intended his Prufrocks and hollow men to warn society of the ruinous effects of a decline in traditional standards of manliness, indeed to ring in a new order of male power, but in fact, Eliot's work actually created a vast lexicon of male crisis, a reservoir of images and metaphors, phrases and descriptions of masculine fallibility which we still draw upon at the end of the twentieth century. 
дарди на машкоста, навистина да заsвони за нов ред во машката моќ, но, всушност, она што Елиотовото дело навистина го создало е голем лексикон за машките кризи, резервоар на слики и метафори, фрази и описи на машката грешност, од што сѐ уште се инспирираме на крајот на дваесеттиот век.

Розмари М. Џорџ, во една многу значајна расправа за односот меѓу модернизмот и појавата на глобалните литератури, ја коментира токму оваа тропа на кризата на машкоста како отсуство или шуплив центар; таа тврди дека и во колонијалните и во постколонијалните дела „машкиот неуспех е ендемски за самата колонијална состојба“. да го покаже опсегот на машката фрагилност во колонијалните записи. Елиотовата песна „Шупливите мажи“, се разбира, сликата за празниот маж ја позајмува од Конрадовиот парадигматски запис за колонијалните и империјалните стравови од импотенција во Срцето на темнината, па песната завршува со цитат од романот: „Госпојн Курц, тој мртов." Конрадовиот роман за бруталноста на цивилизациската мисија многупати бил и критикуван и имитиран во последниве 80 години и сѐ уште ја има моќта да биде парадигматски израз на западната супериорност и остар напад врз модерните методи на колонијално владеење. Џорџ корисно го ситуира Конрад како „важна појдовна точка за незападното сфаќање на западот"(89) и како „фикционален зачеток на цел жанр на интернационално пишување на англиски јазик во двесеттиот век"(90). Навистина, Џорџ тврди дека Конрадовиот текст останува „жив" како колонијалните и постколонијалните документи во нивните „реинкарнации“, што значи во романите и филмовите што ги поттикнале" (90). ${ }^{9}$ На пример, кинематографскиот римејк на Срцето на темнината, Апокалипса сега, ја употребува приказната за осамениот маж кој плови по својот пат низ хаосот и кошмарот за да ја оживее англиската и белгиската колонијална окупација на Конго како американската неоколонијална окупација на Виетнам. Во Апокалипса сега ги наоѓаме остатоците на колонијалните ставови од кои се информирал Конрад, а Франсис Форд Копола употребува систем на империјална логика во кој „ре-
Rosemary M. George, in a very important discussion of the relationship between modernism and the emergence of global literatures comments precisely upon this trope of masculine crisis as absence or a hollow center; in both colonial and postcolonial works, she argues, "masculine failure is endemic to the very colonial situation.". ${ }^{8}$ And George turns to the work of Joseph Conrad to demonstrate the reach of even the most colonial records of male fragility. Eliot's poem, "The Hollow Men," borrows the image of the empty male self, of course, from Conrad's paradigmatic record of colonial and imperial fears of impotence, Heart of Darkness and a quote from the novel frames the poem: "Mistah Kurtz, he dead." Conrad's novel about the brutality of the civilizing mission has been both critiqued and imitated many times over the last 80 years, and it still retains its power as both a paradigmatic expression of Western superiority and a scathing attack on modern methods of colonial governance. George situates Conrad helpfully as "an important starting point for a non-western understanding of the west" (89) and as "the fictional originary for a whole genre of international twentieth century writing in the English language" (90). Indeed, George argues that Conrad's texts remain "alive" as both colonial and postcolonial documents in "their "reincarnations," that is, in the novels and films they have engendered" (90). ${ }^{9}$ For example, in a cinematic remake of Heart of Darkness, Apocalypse Now uses the narrative of the lone male navigating his way into chaos and nightmare to recast the English and Belgian colonial occupation of the Congo as the American neo-colonial occupation of Vietnam. In Apocalypse Now, we find the lingering remains of the colonial mindset that informed Conrad and Francis Ford Coppola deploys a system of imperial logic within which "order" and "bureaucracy" are established as representative of civilized rule and "disorder" and "chaos" are marked as the primitive terrain of the other. 
дот“ и "бирократијата" се етаблирани како претставници на цивилизираниот закон, а „нередот“ и „хаосот“ се обележани како примитивната почва на другото.

Додека Џорџиното дело се обидуваше да ги согледа придонесите на Конрадовото дело за современата литература, Срцето на темнината, се разбира, почесто е читано како канонска артикулација на империјалната мажественост, во која империјалистичкиот машки субјект изискува друга, подмолна мажественост, за да ја оправда колонијалната интервенција. Токму ваквата артикулација на империјалистичката мажественост во Срцето на темнината ја наведува Чинуа Ачиби да тврди за Конрад: „Никој ли не може да ја види во тоа апсурдната и перверзна ароганција, улогата на Африка да се редуцира на потпора за кршењето на дробниот европски ум?"10 Читајки друга преработка на Срцето на темнината, сакам да ја проследам Џорџината идеја дека Конрадовиот текст ја овозможува современата интернационална литература, но имајте го предвид и фактот дека тие исто, ако не и повеќе, би можеле да произведат современ мажествен жанр кој само ќe ја репродуцира колонијалната логика што Конрад ја исцртува во својот роман.

Првиот говор на Марлоу во Срцето на темината го опишува Лондон обвиткан од магла и заглавен во историјата. „И тоа,“ рече Марлоу, „беше едно од мрачните места на земјава." 1 Прогонувачките зборови на Марлоу,кои како да се излеале од мноштвото претходни конверзации и други нарации, лесно би можеле да бидат почетни во прочуената книга на Бил Бафорд од 1990 Меѓу силешиите. Бафорд, уредникот на англиското литературно списание ГРАНТА, ја напишал Meŕy силеџиите како наративен резултат од времето што го поминал меѓу фудбалските навивачи во Англија. Сепак, наместо да го цитира Конрад во почетокот на својата нарација, тој го цитира лордот Баден-Пауел, основачот на извидниците, кој го оплакува опаѓањето на англиската мажественост во 1908 поради транссормацијата на атлетите во спортски навивачи. Откако ќе го опише феноменот на раниот дваесетти век, кога потрошувачки толпи сочинети од „бледи, тесногради, подгрбавени, ми-
While George's work tried to recognize the contributions of Conrad's oeuvre to the development of world literature, Heart of Darkness is, of course, more often read as the canonical articulation of imperial masculinity within which the imperialist masculine subject requires an other, abject masculinity to justify colonial intervention. It is precisely this articulation of imperialist masculinity in Heart of Darkness that leads Chinua Achebe to assert about Conrad: "Can nobody see the preposterous and perverse arrogance in thus reducing Africa to the role of props for the break-up of one petty European mind?"10 In a reading of another contemporary rewriting of Heart of Darkness, I want to pursue George's idea that Conrad's texts enable a contemporary international literature but also keep in mind the fact that they are equaliy, if not more, likely to generate a contemporary masculinist genre which simply reproduces the colonial logics that Conrad maps out in his novel.

Marlowe's first speech in Heart of Darkness describes a London shrouded in fog and stymied in history: "And this also," said Marlowe, "has been one of the dark places of the earth." 11 Marlowe's haunting words which seem to spill from a multitude of prior conversations and other narratives could as easily open Bill Buford's celebrated 1990 book Among the Thugs. Buford, the editor of an English literary magazine GRANTA, wrote Among the Thugs as a narrative account of his time spent among football fans in England. Rather than citing Conrad at the opening of his narrative, however, Buford cites Lord Baden-Powell, the founder of the boy scouts, lamenting the decline of English masculinity in 1908 on account of the transformation of the athlete into the sports fan. After describing the early twentieth century phenomenon of paying crowds made up of "pale, narrow chested, hunched up, miserable specimens" flocking to watch football matches, Baden-Powell demands: "Get the lads away from this--teach them to be manly."'2 Obviously, Baden-Powell's 
зерни примероци“ се ројат за да гледаат фудбалски натпревари, Баден-Пауел бара: „Тргнете ги момчињата подалеку од ова - научете ги да бидат мажествени."12 Очигледно, Бафорд ги цитира Баден-Пауеловите зборови како потсетник на историјата на мажественоста и нејзината вовлеченост во спортот, особено во фудбалот; сепак, како што се развива неговата нарација и како што Бафорд се спушта во сегашното британско срце на темнината - светот на фудбалските силеџии - станува сѐ поочигледно дека Бафорд ги дели Баден-Пауловите империјални сфаќања за машкоста како компулзивност на современиот човек спрема редот, силината, активноста, грубиот индивидуализам и самоконтролата.

Во белешката на задната корица на Меѓу силеџиите, на Бил Бафорд му е оддадено признание како на храбар истражувач кој „влегува во алтернативното општество“ на фудбалски хулигани „и ги бележи и неговите дивеења и неговата општествена маѓепсувачка моќ..." Бафорд своите англиски средби ги опишува како спуштање во дивјачка територија населена со бестијални личности со имиња како Овча Кременадла, Барни Мрднатиот, Доналд Будалиот и Семи Смачкувачот. Овие фудбалски фанови различно се опишани како „дебели“, „надуени", „месести и закрвавени". Неговата прва средба е со навивач на Манчестер Јунајтед наречен Мајк кого тој го опишува вака:

„Тој имаше дебело, сплескано лице како булдог и беше огромен. Маицата му се дигаше по стомакот и беше обезбоена од нешто лепливо и темно. Стомакот му беше нешто како каца $и$ открив дека во него се мешаат литри и литри пиво, делумно изџвакани пржени компирчиња и влажни, недоволно сварени топчиња преработени јаглени хидрати. Рацете - надуени, крофнести нешта, му беа извалкани од тетоважи." (26)

Преку Мајк, со овој опис, се дефинира прекумерноста. Тој има премногу месо, неподвижно, крофнесто месо; тој е непребирлив консумент на лоша храна од што телото му станува млитаво и нездраво. Мајк е сведен на неговите непривлечни делови од телото, кога Бафорд од описот на неговото „дебело, сплескано лице“ ќе премине на words are cited by Buford as an ironic reminder of the history of masculinity and its imbrication in sports and football in particular; however, as his narrative unfolds and as Buford descends into England's present heart of darkness--the world of the football thug--it becomes more and more obvious that Buford shares Baden-Powell's imperial conception of manliness as the civilized's man's compulsion towards order, vigor, activity, rugged individualism and self-restraint.

On the back cover blurb to Among the Thugs, Bill Buford is credited as a brave explorer who "enters an alternate society" of soccer hooligans "and records both its savageries and its social allure..." Buford himself describes his English encounters very much in terms of a descent into a savage territory peopled by bestial characters with names like Mutton Chops, Barmie Bernie, Daft Donald and Steamin' Sammy. These football fans are variously described as "fat," "bloated," "puffy and bloodshot." His first encounter is with a Manchester United fan called Mick whom he describes in the following terms:

He had a fat, flat bulldog face and was extremely large. His t-shirt had inched its way up his belly and was discolored by something sticky and dark. The belly itself was a tub of sorts, swirling, I would discover, with liters and liters of lager, partly chewed chunks of fried potato, and moist, undigested balls of over-processed carbohydrate. His arms--puffy, doughy things, were stained with tattoos (26).

Mick, in this description, defines excess. He has too much flesh, unmoving and doughy flesh at that; he is an indiscriminate consumer of bad food which then marks the body as un-nourished and unhealthful. Mick is also reduced to his unsightly body parts as Buford moves from describing his "fat flat face" to commenting upon "the belly" as if it existed separate 
коментирање на "стомакот“ како тој да е независен од Мајк. Слично на ова, Мајковите раце се опишани речиси како да не се прицврстени за Мајк, наместо тоа, тие се „надуени, крофнести нешта" кои, како и неговата маица, се „исфлекани". Во овој опис Мајк не е многу различен од "црните облици", сенковитите домородечки фигури што го населуваат Конрадовото Срце на темнината.

Бафорд својата книга му ја презентира на читателот (а таа е главно така и прифатена), како книга за значајниот фудбалски хулиганизам што создава алтернатива на моралистичката социолошка литература (од која има голема архива) и ги дијагностицира болестите на британското општество преку фигурата на најспектакуларниот неуспех на тоа општество: несмасниот пивопиец. Бафорд тврди дека употребата на серија лични приказни, наспроти објективните социолошки прикази, е најпогодна за претставување на променливата и експлозивна природа на "толпата" во врска со феноменот на фудбалскиот хулиганизам. Понатаму, тој образложува дека социолошката литература го сфаќа насилството на толпата на редуктивни начини, како „симлтоматично за гниењето на нашето време" или како "фундаментално не различно од она што било вчера“. Бафорд продолжува така што својата нарација ја одделува од овие тези, очигледно отфрлајќи го сфаќањето дека насилството на толпата секогаш го претставува насилството на другите. Наместо тоа, тој тврди дека "толпата е во сите нас" (249). Во еден страствен пасус Бафорд ни предлага да размислиме зошто секогаш сметаме дека толпата е подалеку од нас:

„Лесно ни е да отпишеме некој инцидент на насилство на толпата во Јужна Африка или Индија, географски и културно далечни земји, очигледно тоа не сме ние; разбирливо е, нели, дека ќе има насилство на бандите таму мегу „неразвиените“, „непривилигираните“, "нецивилизираните“, „примитивните“ (според метафорите од деветнаесеттиот век). Но, исто така ни е лесно да го отпишеме насилството надвор од вратите на нашите домови. Тука, сега, во Англија, во Лондон, во споредна улица, недалеку од центарот, се збира толпа, но таа толпа, инсистираме, не сме ние." (186) from Mick himself. Similarly, Mick's arms are barely recognized as attached to Mick, they are instead "puffy, doughy things" which like his t-shirt have become "stained." Mick in this description is not much different from the "black shapes," the shadowy native figures which people Conrad's Heart of Darkness.

Buford presents his book to the reader, and indeed it is generally received as, an account football hooliganism which forms an alternative to the moralistic social science literature (of which there is a vast archive) which diagnoses the ills of British society through the figure of its most spectacular failure: the lager lout. Buford claims that his use of a set of personal voice narratives, as opposed to a sociological objective account, is best suited to represent the mercurial and explosive nature of "the crowd" in relation to the phenomenon of soccer hooliganism. He further argues that the social science literature views crowd violence in reductive ways as either "symptomatic of the rot of our times" or else "fundamentally no different from what it was yesterday." Buford then goes on to distinguish his narrative from these accounts by apparently rejecting the notion that crowd violence always represents the violence of the other, instead, he claims, "the crowd is in all of us" (249). In one passionate passage Buford asks us to contemplate why we always think the crowd is elsewhere:

It is easy to dismiss an incident of crowd violence in South Africa or India, countries that removed in both geography and culture, are manifestly not us; it makes sense--does it not?-- that there, among the 'underdeveloped,' the 'underprivileged, the 'uncivilized, the primitive (our nineteenth century metaphors reemerge) there would be mob violence. But it is as easy to dismiss the violence outside the doors of our homes. Here, now, in England, in London, down a side street, not far from the center, there is a crowd assembling, but that crowd, we will insist, is not us (186). 
Ова е комплициран пасус, барем затоа што се чини дека Бафорд е целосно свесен за сфакањата на деветнаесеттиот век за цивилизацијата и развојот, кои се основа за карактеризирање на младите од работничката класа во Англија. Но, кога поттурнувањето станува туркање, буквално, кога, според силеџискиот израз, насилството „настапува“, Бафорд се наоѓ на сосема другата страна од оваа критика, повторувајќ́ дека, иако е меѓу силеџиите, тој дефинитивно не е еден од нив. Во Бафордовиот лирски лет одекнува една Елиотова песна, една од „Четирите квартети", "Мала замаеност“, каде што Елиот пишува за бомбардирањето на Англија во Втората светска војна и смета дека Англија била трансформирана од седиште на империјата во крај на светот:

Има и други места

Што се крај на светот, некои во челустите на морето

Или над мрачното езеро, во пустина или во град

Но, ова е најблиску, по време, по место,

Сега, во Англија. ${ }^{13}$

„Тука, сега, во Англија,“ пишува Бафорд, „во Лондон, во споредна улица, недалеку од центарот..." ќе најдеме толпа, банда, бесчувствителна маса на другоста. "Сега, во Англија,“ пишува Елиот, ќе стигнеме до крајот на светот, ќе стигнеме „од каде што тргнавме/ И ќе го дознаеме местото за првпат." Додека Елиот барем ги признава крајот на империјата, крајот на истражувањето, крајот на потрагата по темни места, додека тој барем признава, како Конрад, дека и ова „било едно од мрачните места на земјата“, се чини дека Бафорд и по четириесет години е шокиран од откритието дека Англија не е земја на благопријатност и светлина, туку дом на спорадично насилство, силеџиски заедници и валкани толпи.

Mеѓy силеџиите е силно и задолжително четиво што се движи во ритмот на фудбалската толпа и е обележано од континуиран циклус од пиење, тепање и повраќaњe. Нарацијата, како што спомнав, се претставува како важен запис за особено одвратната форма на националистичката мажественост налик на "скинхедсите“, отелотворена во лицата што ги нарекуваме „дечки“, „хулигани“
This is a complicated passage if only because Buford seems to be completely aware of the nineteenth century logics of civilization and development which subtend the characterization of working class youth in England. But when push comes to shove, literally, when the violence, in the thug slang, "goes off," Buford finds himself on quite the other side of this critique arguing over and over that though he may be among the thugs, he definitely is not one of them; though the crowd ultimately may be in them, it is not and never has been in him. Buford's flight of lyricism, moreover, echoes an Eliot poem, one of his Four Quartets, "Little Gidding," where Eliot writes about the bombed out England of World War 2 and finds that England has been transformed from the seat of empire to the world's end:

There are other places

Which also are the world's end, some at the sea jaws, Or over a dark lake, in a desert or a city--

But this is the nearest, in place and time, Now and in England. ${ }^{13}$

"Here, now in England," writes Buford, "in London, down a side street, not far from the center..." we will find a crowd, a mob, an insensible mass of otherness. "Now and in England," writes Eliot, we will arrive at the end of the world, we will arrive "where we started/And know the place for the first time." While Eliot, at least, acknowledges the end of empire, the end of exploration, the end of the search for the world's dark places and while he at least recognizes, like Conrad, that this too "has been one of the dark places of the earth," Buford seems shocked some forty years later to find that England is not the land of sweetness and light but a home to random violence, thug community and the ignominy of the crowd.

Among the Thugs is a compelling and compulsive read which moves to the rhythm of the football crowd and is punctuated by its continuous cycle of drinking, singing, fighting and puking. The narrative, as I have suggested, presents itself as an important record of one particularly repulsive form of nationalist skin head masculinity embodied in those figures variously referred to as "lads," "hooligans" and "thugs." The real agenda of 
и „силеџии“. Сепак, главната програма на нарацијата е темпераментна одбрана на друга форма мажественост што можеме да ја наречеме империјалистичка мажественост и која функционира токму преку исцртувањето суштествени и дефинитивни дистинкции меѓ „надуениот код на мажевноста" својствен за мажественостите на работничката класа и пишаните и цивилизирани кодови својствени на мажественоста на средната класа, како и да ја дефинираме. Книгата е преполна со слики од кои читателот треба да ги препознае, забележи и одобри обликот и силината на Бафордовото дистанцирање од „мизерните примероци“ што го опкружуваат. Низ целата нарација Бафорд се опишува себеси како симултано одбиен, фасциниран и контаминиран од насилството на кое е сведок; но, на крајот, се плаши дека ќе биде повлечен преку работ на целосното растворање. Во завршните страници на книгата, тој отстапува пред насилството и хоророт уште на една сцена со толпа, во која споулавени англиски момчиња се дерат по улиците на Сардинија за време на фудбалски натпревар од светското првенство, бркани од италијанската полиција. Во бруталниот расплет, Бафорд се наоѓa свиткан на улицата, претепан од италијанските полицајци со пендреци, прашувајќи се зошто тие не препознале дека тој очигледно не е насилник. Како што се секава на секој удар врз бубрезите и главата, тој се сеќва и на мислата што го тешела сред трауматичното тепање: „Сево ова беше исклучително болно, како што и би очекувале, но, моето искуство од ова беше различно од она на другите што беа претепани. Нивното искуство беше едноставно - болка. За мене беше покомплицирано, бидејќи знаев дека ќе пишувам за него." (307)

Bo Meѓy силециите Бафорд наоѓа бекство и утеха преку тоа што себеси се идентификува како оној што пишува, оној што забележува, оној што собира информации. Токму оваа идентификација од неговата нарација создава, и покрај неговите најдобри намери, форма на империјална мажественост. Овој жанр на мажественост почива врз три различни претпоставки во нарацијата: прво, Бафорд апсолутно верува во тоа дека може да биде меѓу силеџиите, а да не биде еден од нив; второ, Бафорд е сигурен дека the narrative however is a spirited defense of another form of masculinity that we can call imperialist masculinity and that functions precisely by drawing essential and definitive distinctions between the "bloated code of maleness" inherent to working class masculinities and the writerly and civilized codes inherent to middle-class masculinity however it may be defined. The book is rife with images that will the reader to recognize, notice and approve the shape and force of Buford's difference from the "miserable specimens" that surround him. Throughout the narrative Buford depicts himself as simultaneously repulsed, fascinated and contaminated by the violence he witnesses; but, ultimately, he fears that he will be drawn over the brink into complete dissolution. In the book's closing pages, he recoils from the violence and the horror of yet another crowd scene in which rabid English lads tear through the streets of Sardinia during a World Cup match, chased by the Italian police. In this brutal denouement, Buford finds himself curled up on the streets being beaten by Italian officers with truncheons and wondering why they have not recognized him as clearly not a thug. As he records the memory of each blow to his kidneys and head, he also recalls the thought that comforted him in the middle of the trauma of being beaten: "All of this was exceptionally painful, as would be expected, but my experience of it was different from that of the others who were being beaten up. Their experience was one of simply pain. For me, it was more complicated, because I knew that I would be writing about it" (307).

Buford finds refuge and comfort in Among the Thugs in the identification of himself as one who writes, one who records, one who collects information. It is this precise identification that produces in his narrative, despite his better intentions, a form of imperial masculinity. This genre of masculinity resides in three different assumptions in the narrative: first, Buford's absolute belief that he can be among the thugs without being of them; second, Buford's sureness that the act of writing rescues males like him from their baser instincts and draws the line between 
чинот на пишување ги ослободува мажите како него од нивните основни инстинкти и ги разграничува нормативните од ненормативните мажествености; и трето, Бафорд неинформирано го употребува терминот „силеџија“ ("thug"), кој има империјална историја.

Во Оксфордскиот енциклопедиски речник "thug" e дефиниран како: „член на религиозна организација на крадци и убијци во Индија, која е укината околу $1825 .$. "thugee" - дејноста на овие силеџии." И "хулиган" има интересна историја: „млад никаквец, еден од бандата грубијани, име на насилничко ирско семејство во Лондон." Јасно е дека обата назива се обележани со расни и колонијални назнаки: "thug" е индиски збор кој преку колонијализацијата влегол во англискиот јазик. Така, прашањето во врска со Бафордовата нарација е ова: што значи тоа што еден индиски термин за бандит станал термин за фудбалските навивачи од Англија? Според Парама Рој во „Откривање на Индија, замислување на разбојништвото“, за оваа група индиски силеџии се претпоставува дека биле убијци по наследство, кои ги начекувале патниците во име на славата на божицата Кали, во XVIII и XIX век. Убивале брзо и тивко, најчесто со давење $n_{1}$ откако ке ги ограбеле жртвите, толку ефикасно се ослободувале од телата, што на властите им било тешко да најдат доказ дека е извршено кривично дело. ${ }^{14}$

Дејствувањето на индиските силеџии, Англичаните во Индија го сметале за усовршен вид заговор, бидејќ ги комбинирал квазирелигиозните тајни братства со усовршениот религиозен ритуал и наследен систем на членство; навистина, англиските мажи биле толку фасцинирани од индиското разбојништво, што се појавиле многу романи со фантазирање за животите и времето на овие силеџии: најпозната меѓу нив е божемно етнографската нарација Исповеди на разбојникот, запишана од Филип Медоуз Тејлор. ${ }^{15}$ Во сиве овие записи, коментира Парама Рој, биле налравени малку обиди на индиското разбојништво да му се дадат политички или економски мотивации. Сепак, како што додава Рој, „современите ученици на колонијалната историја сакале да дадат алтернативен, поматеријалис- normative and non-normative masculinities; and third Buford's uninformed deployment of the term "thug," an appellation with its own imperial history.

The OED defines "thug" as: "member of religious organization of robbers and assassins in India suppressed around 1825...THUGGEE - the practice of Thugs." Hooligan also has an interesting history: "young ruffian, one of a gang of roughs, name of ruffianly Irish family in London." Both names, it is clear, are marked by racial and colonial terms: "thug," it turns out is a Hindi word which entered the English language through colonialism. The question in relation to Buford's narrative then is this: What does it mean that a Hindi term for an Indian bandit becomes the term for working class English football fans? According to Parama Roy in "Discovering India, Imagining Thuggee," thugs were a group of supposedly hereditary killers in India who preyed on travelers as an act of worship to the Goddess Kali in the $18^{\text {th }}$ and $19^{\text {th }}$ centuries. They killed quickly and silentiy, usually by strangulation, and, after robbing their victims, they disposed of the bodies so efficiently that authorities had a hard time ever finding proof that a crime had been committed. ${ }^{14}$

The practice of the thugs was considered by the English in India to be an elaborate kind of conspiracy since it combined quasi-religious secret fraternities with elaborate religious ritual and a hereditary system of membership; indeed, English men were so fascinated by thuggee that a number of novels appeared fantasizing about the life and times of the thug: and the best known of these is the supposedly ethnographic narrative Confessions of a Thug inscribed by Philip Meadows Taylor. ${ }^{15}$ In all of these accounts, as Parama Roy comments, few attempts were made to provide thuggee with political or economic motivations. However, as Roy adds, "twentieth century scholars of colonial history have sought to posit alternative, more materialist histories of the phenomenon" (123). These other more materialist explanations see the thugs as either people working 
тички приказ на овој феномен“ (123). Овие поматеријалистички објаснувања ги гледаат индиските разбојници или како луѓе што работеле против колонијалниот закон воспоставен од моќните колонијални владетели, или како локални групи, речиси платеници, најмени од соседствата, за заштита. Овие согледби го нагласуваат тоа дека Англичаните го сфаќале индиското разбојништво како ирационално, брутално и во основа криминално, затоа што ваквиот опис придонесувал, како што вели Рој, кон „сѐ уште растечкиот проект на откривање на Индија“. Со оглед на тоа дека овие разбојници биле таинствени и тешко било да им се влезе во трагата, англиската колонијална полиција барала исповеди од соработници, па нивните искази ги користела за да ја утврди „вистината" за разбојниците, да ги идентификува потенцијалните разбојници, но и да го оправда проектот на колонијалното владеење.

Кои се импликациите од оваа колонијална историја за современиот феномен на документирање на фудбалското силеџиство? Прво, и во двата контекста силеџиството е ограничено на одредени тела, фамилии и региони. Второ, во двата случаја, силеџиите се користат за да се оправда екстремното полициско насилство, но и да се испробаат некои политички техники. Трето, во обата случаја, омилена политичка техника е етнографската. Така, можеме да зборуваме за архива за разбојништвото во Индија, сочинета од колонијални записи и романи за разбојниците и исповеди од нив; но, исто така можеме да зборуваме за современата социолошка фудбалска „силеџиска архива" во Англија, сочинета од текстови, нарации, безбедносни планови и полициски документи. ${ }^{16}$ Конечно, употребата на терминот „силеџија“ во врска и со младите фудбалски навивачи во Англија и индиските бандити исцртува особена колонијална историја на односите меѓу отпадниците и доминантните мажествености. Терминот „силеџија“ исцртува расистички и колонијален план за владеење развиен во Индија, па донесен во Англија за да владее врз опасните пониски класи. Во постколонијална Англија, силеџијата веке не е некаде таму, тој е тука, а техниките за негово препознавање и контролирање, развиени во Индија, се употребуваат и дома. against colonial rule who had been displaced as rulers by the colonial powers, or as local groups, almost mercenaries, hired by neighborhoods for protection. What these accounts stress is that the English conceived of Thuggee as irrational, brutal and essentially criminal because such a depiction contributed to, as Roy puts it, "the still emerging project of discovering India." Because thugs were secretive and difficult to track down, English colonial police solicited confessions from informers and then used their accounts to establish the "truth" of the thugs, to identify potential thugs but also to justify the project of colonial rule.

What are the implications of this colonial history for the contemporary phenomenon of documenting the football thug? First, in both contexts thug violence is essentialized to particular bodies, families and regions. Second, in both cases, thugs are used to justify extreme police violence but also to test drive certain policing techniques. Third, in both cases, the favored policing technique is that of ethnography. Thus, we can talk about a Thuggee archive in India made up of colonial accounts and novels about thugs and confessions by thugs; but we can also think in contemporary terms of a social science soccer "thug archive" in England made up of texts, narratives, security plans and police documents. ${ }^{16}$ Finally, the use of the term thug in relation to both the young soccer fan in England and the Indian bandit maps a particular colonial history of the relations between outlaw and dominant masculinities. The term "thug" maps a racialized and colonial plan of governance developed in India and then brought home to rule the dangerous lower classes. In a post-colonial England, the thug is no longer over there, he is here and the techniques for controlling and knowing him developed in India are deployed at home. 
Бафордовата нарација, особено со оглед на тоа дека тој не е Англичанец, туку странец, Американец, придонесува кон силеџиската архива, архива што создава карикатура за глупавиот, бестијален и див фудбалски навивач, за да ги глорифицира и оживотвори мажественостите на средната класа по падот на империјата. Додека за Бафорд толпата го претставува менталитетот на стадото, а не нешто возвишено како политички колективитет, неговото сопствено одбивање на толпата за него не значи елитен чин на диференцијација, туку херојски чин што ја потврдува суштествено цивилизираната и подредувачката природа на мажот од средната класа кој не се бори, туку пишува. Шупливиот маж, „маса без облик/ Парализирана сила, гест без движење," кој е империјалната мажественост забележана од Бафорд, низ својата близина да ја открива единствено својата одвоеност од она што тој го нарекува „антицивилизирана“ возбуда „да се биде во толпата при чин на насилство" (193). Бафорд се воодушевува од мажествената силина на толпата, но во исто време инсистира дека возбудата е позајмена, таа е од чувството за опседнатост што ја потврдува неговата мажес-твеност, а сепак му се заканува дека ќе го уништи. На крајот, тој бргу се враќa кон она што го нарекува „состојба да се биде граѓанин, да се биде цивилизиран.“ И продолжува: „Го сфаќам како мрежа што ме држи на место, ме спречува да паднам“ (193). Додека зјапа во празнината - насилство, толпа, беззаба уста на силеџијата - Бафорд знае дека стигнал длабоко во срцето на темнината и дека ќе преживее за да ја раскаже приказната.

\section{2. „Trainspotting" и Како од мајка родени: постимперијални мажествености}

Во овој дел од мојот текст сакам да разгледам една друга нарација за британската мажественост, кажана не од некој што очајнички се држи до својата позиција во средениот универзум, туку од машки наратори кои за суштински во своите приказни за мажественоста на дваесеттиот век, ги замаат импотентноста, понижувањата и губењето на мажествениот авторитет. Неодамнешните учења во неколку различни дисциплини се обидуваат да ја
Buford's narrative, particularly since he is not English but an outsider, an American, contributes to the thug archive, an archive which produces the caricature of the dumb, bestial and savage football fan in order to glorify and reinvigorate middleclass masculinities after the decline of empire. While the crowd, for Buford, represents a herd mentality rather than anything as dignified as a political collectivity, his own individualist rejection of the crowd signifies to him not as an elite act of differentiation, but as a heroic gesture which confirms the essentially civilized and orderly nature of the middle-class man who writes rather than fights. No longer the hollow man, "shape without form, shade without color/Paralysed force, gesture without motion," the imperial masculinity recorded by Buford revels in its proximity to but separation from what he calls the "anticivilized" excitement of "being in a crowd in an act of violence" (193). Buford thrills to the manly vigor of the crowd but simultaneously insists that the thrill is borrowed, a flair of obsession that confirms his masculinity and yet threatens to obliterate him. Ultimately he runs back to what he calls "this state of being a citizen, of being civilized." And he continues: "I see it as a net that holds me in place, keeps me from falling" (193). As he peers into the void--violence, the crowd, the toothless mouth of a thug --Buford knows that he has arrived deep in the heart of darkness and that he will survive to tell the tale.

\section{Trainspotting and The Full Monty: Post-Imperial Masculinities}

In this next section of my paper, I want to look at a different narrative of British masculinity, one told not by a subject desperately holding on to his place in an ordered universe but by male narrators who make impotence, humility and the loss of masculine authority into the very essence of their stories about late twentieth century masculinity. Recent scholarship in several different disciplines has tried to address the possibility of a new politics of manhood but all too often these new and 
именуват можноста за нова политика на човештвото, но многу често овие нови и различни концепти за мажите и мажественоста ја наметнуваат идејата за решавање на „кризата" на мажественоста. Филип Брајан Харпер во својата влијателна книга за црнечката мажественост, Не сме ли мажи, за цел го има токму овој метод на дијагностицирање на болестите на машкиот род: „кога пошироката култура смета дека во африканско-американското општество има перманентна „криза“ на црнечката мажественост, замисленото решение секогаш е вистинска афирмација на авторитетот на мажот - црнец." 7 Ова сфаќање дека дестабилизацијата на мажественоста резултира со криза и дека кризата изискува моментна консолидација на машкиот авторитет, го поткрепува она што јас го нарекувам империјална мажественост. Од друга страна, постимперијалните мажествености одбиваат да му се потчинат на сфаќањето за кризата на мажественоста и намерно одбиваат да го зацврстат машкиот авторитет; наместо тоа, тие активно придонесуваат за негово разјаснување.

Земајки го предвид сериозниот, мрачен и страотен тон на Бафордовиот модернистички приказ на белечките скапаници и насилници од работничката класа на Англија, кои се закануваат дека ќ ја турнат нацијата кон работ на анархијата, интересно е да се забележи дека сите места што ги одбрав за претставување на постимперијалните мажествености се комични. Злобните пародични одбивања на машкиот авторитет се во контраст со депресивните и сериозни приказни за белците од средната класа преку безбожничките, самоосудувачките, непристојните и хумористични стории за постимперијалните мажествености. На пример, озлогласениот класичен роман за скапаниците на Ирвин Велч Trainspotting (од кого беше направен филм во 1996) стремежите и неволите на невработената шкотска младина што сака да побегне од Тачерината Британија (од невработеноста и црната сиромаштија) ги опишува со див хумор и досетливост. ${ }^{18}$ Рентон, антихеројот на романот и еден од петте наратори во текстот, ја одбива вообичаената развојна патека на наративна прогресија и своето време го минува движејќ се напред-назад мегу екстазата на дрогите и агонијата на здодевноста. Тој нема период different concepts of men and masculinity turn on the idea of resolving the "crisis" of masculinity. Philip Brian Harper, in his influential book on black masculinity, Are We Not Men, takes aim at precisely this method of diagnosing the ills of manhood: "when (the) broader culture conceives of African-American society in terms of a perennial "crisis" of black masculinity," the "imagined solution is (always) a proper affirmation of black male authority." ${ }^{17}$ This notion that the destabilization of masculinity results in crisis and, that crisis demands the immediate reconsolidation of male authority, underpins much of what I am calling imperial masculinity. Post-imperial masculinities on the other hand refuse to submit to the notion of masculinity in crisis and they also deliberately refuse to reconsolidate male authority; rather, they contribute actively to its unraveling.

Given the serious, dark, dire and moralistic tone of Buford's modernist account of the white working class punks and thugs in England, who threaten to push the nation to the brink of anarchy, it is interesting to note that the sites I have chosen to represent post-imperial masculinities all happen to be comic. These wickedly parodic refusals of male authority contrast depressing and earnest tales of middle-class white manhood to irreverent, self-deprecating, foul-mouthed and humorous stories of post-imperialist masculinities. For example, Irvine Welch's notorious punk classic novel Trainspotting (also made into a film in 1996) depicts the trials and tribulations of unemployed Scottish youth seeking some escape from Thatcher's Britain, (unemployment and blistering poverty) with ferocious humor and wit. ${ }^{18}$ Renton, the novel's anti-hero and one of about five narrators in the text, refuses the usual developmental trajectory of narrative progression and spends his time shuttling back and forth between the ecstasy of drugs and the agony of boredom. He undergoes no period of maturation, he makes no progress, neither he nor his mates learn any lessons, no one quits the bad life and ultimately many of them die from drugs, HIV, violence, neglect. Renton explicitly acknowledges his re- 
на созревање, не прави прогрес, ни тој ниту неговите другари не научуваат ништо, никој не го напушта лошиот живот и на крајот многумина од нив умираат од дрога, сида, насилство, негрижа. Рентон експлицитно го признава своето одбивање на нормативен модел на развој и одбивањето го претвора во горчлива критика на либералното сфаќање за изборот:

„Да претпостајме дека ги глеам добрите и лошите страни, дека знам дека ќе живеам кратко, дека сум здрав у тоа мозокот, итн., итн., ама ипак сакам да се надувам. Тие нема да ме пуштат. Тие нема да ме пуштат, оти тоа го глеат како знак на својот крах. Тоа дека едноставно си одбрал да го одбиеш она шо ти го понудиле. Одбери нѐ нас. Одбери го животот. Одбери да плаќаш хипотека; одбери си машина за перење; одбери си кола; одбери да се квакнеш на кауч и да глеаш заглупувачки и затупувачки квизови; бутај брза храна во муцката. Одбери да изгниеш, да мочаш и какаш по дома, за целосен срам на себичните заебани копуци шо си ги створил. Одбери го животот. Па, ја одбрав да не го одберам животот. Ако тие пиздите не можат да се справат со тоа, шо ги вртам. Ко шо вика Хери Лодер, иам намера да одам до крајот на патот..."

Рентоновиот избор да не го одбере „животот“ го става во радикална опозиција спрема моделите на машката респектибилност, но му дава и простор да ја обелодени контрадикторната логика на здравје, среќа и праведност во поранешната добростоечка држава. Во неговиот брилијантен злобен говор, тоа што ја одбира дрогата наспрема здравјето, Рентон го оправдува со тоа дека „не го одбрал животот“, а „животот“, според него, значи: „плаќање хипотека, машини за перење, автомобили, седење на кауч, гледање заглупувачки и затапувачки квизови, полнење на устата со брза храна, гниење во домаќинството." Тој не вели дека општеството „создава лажна, искривена логика за да ги апсорбира луѓето чие однесување е надвор од главниот тек“ (187). Во ова сфаќање „животот“, заглупувачкиот начин на домашна пасивност сочинува подобар морален „избор“ отколку животот со дрога и алкохол; истото сфаќање на младиот човек му ги нуди вооружените fusal of a normative model of self-development and turns this refusal into a bitter critique of the liberal concept of choice:

"Suppose that ah ken aw the pros and cons, know that ah'm gaunnae huv a short life, am ay sound mind etcetera, etcetera, but still want tae use smack? They won't let ye dae it. They won't let ye dae it, because it's seen as a sign of thir ain failure. The fact that ye jist simply choose tae reject whit they huv tae offer. Choose us. Choose life. Choose mortgage payments; choose washing machines; choose cars; choose sitting oan a couch watching mind-numbing and spiritcrushing game shows; stuffing fuckin junk food intae yir mooth. Choose rotting away, pishing and shiteing yersel in a home, a total fuckin embarassment tae the selfish, fucked-up brats ye've produced. Choose life. Well, ah choose not tae choose life. If the cunts cannae handle that, it's thair fuckin problem. As Harry Lauder sais, ah jist intend tae keep right on to the end of the road..."

Renton's choice to not choose "life" situates him in radical opposition to modes of masculine respectability but also gives him space to expose the contradictory logic of health, happiness and justice within the post-welfare state. In this brilliantly wicked speech, Renton justifies his choice of drugs over health as a choice "not to choose life," where "life" signifies in his words: "mortgage payments, washing machines, cars, sitting on the couch watching mind numbing and spirit crushing game shows, stuffing junk food into your mouth, rotting away in domesticity." Society, he tells us, "invents a spurious convoluted logic to absorb people whose behavior is outside its mainstream" (187); within this logic "life," a numbing mode of domestic passivity constitutes a better moral "choice" than a life of drugs and drink; this same logic offers the armed forces to young men over street gangs and marriage over sexual promiscuity. 
сили наспроти уличните банди и бракот наспроти сексуалниот промискуитет.

Дури и во интелектуалните моменти, Рентоновото теоретизирање е поттикнато од намерно одбивање на машкиот авторитет, самосвесно отфрлање на сфаќањето на методолошка аргументација. Рентон ја одбира пцовката место рационалната мисла, како своја аналитичка алатка На пример, во острата дијатриба против Англичаните затоа што ја колонизирале Шкотска и против Шкотите што им го дозволиле тоа, тој беснее: „Бегби и сличните се ебени несреќи во земја на несреќи. Не треба да ги окривуваме Англичаните што не колонизирале. Не ги мразам Англичаните, тие се само смотаници. Ние сме колонизирани од смотаници. Не можевме дури ни да одбереме пристојна, активна, здрава култура да нѐ колонизира. Не. Нѐ владеат истоштени глупаци. Тоа значи дека ние сме шо? Најдолни меѓу долните, џганот на земјава. Најбедното, најсервилното, најмизерното, најпатетичното ѓубре шо уопште се створило. Не ги мразам Англичаните. Тоа лајно шо го имаат, тоа си го носат. Ги мразам Шкотите." (78). Рентоновата дијатриба можеби не ќе добие поени за инспиративните квалитети; сепак, таа е зла и потентна критика на британскиот колонијализам, од една страна, и на лажно оптимистичната реторика на антиколонијалниот национализам, од друга страна. Во друг контекст, Лиза Лоу го нарекува пишувањето што го одбива бинаризмот на колонијализмот наспроти национализмот „деколонизирачко пишување“, што за неа е „прогресивен прекин на колонијалниот начин на продукција." 9 Возовите минуваат, шкотскиот деколонизирачки роман, ги претставува дрогата, кражбата и насилството како единствени алатки што им преостанале на колонизираните мажи и на мажите од средната класа во единбуршките гета.

Романот, за разлика од романите чија цел е да ги зацврстат империјалните мажествености, открива растечко незадоволство од конвенционалниот заплет во врска и со минатото и со иднината, или како утопија или како дистопија, а Велч нѐ тера да смислиме покомплексни исцртувања на просторот и времето. Мишел Фуко во прилогот
Even in his intellectual moments, Renton's theorizing is driven by a deliberate refusal of masculine authority, a selfconscious rejection of the logic of methodical argumentation; Renton selects the curse rather than rational thought as his analytic tool. For example in a scathing diatribe against the English for colonizing Scotland and the Scottish for letting them, he rants: "Begbie and the like are fucking failures in a country ay failures. It's no good blaming it on the English for colonizing us. Ah don't hate the English, they're just wankers. We are colonised by wankers. We can't even pick decent, vibrant, healthy culture to be colonized by. No. We're ruled by effete arseholes. What does that make us? The lowest of the low, the scum of the earth. The most wretched, servile, miserable, pathetic trash that was ever shat into creation. I don't hate the English. They just get on with the shit they've got. I hate the Scots" (78). Renton's diatribe may not win points for its inspirational qualities; however, it is a mean and potent critique of British colonialism on the one hand and of the falsely optimistic rhetoric of anti-colonial nationalism on the other. In a very different context, Lisa Lowe has called writing which refuses the binary of colonialism versus nationalism as "decolonizing writing" which she calls "an ongoing disruption of the colonial mode of production." "19 Trainspotting, a Scottish decolonizing novel, envisions drugs, theft and violence as the only tools left to the colonized and working-class males of Edinburgh's slums.

This novel, unlike novels aimed at fortifying imperial masculinities, reveals an increasing dissatisfaction with the conventional plotting of both the present and the future in terms of either utopia or dystopia and Welch forces us to come up with other more complex mappings of space and time. Michel Foucault in an article called "Of Other Spaces" develops the notion 
наречен „За другите простори“ го развива концептот за „хетеротопија“ како алтернативна историја на просторот. Фуко исцртува конвенционален модел на историја во која минатото го претставува просторот на мртвите, а иднината, просторот на можностите. Сепак, тој тврди дека веќе не можеме да ставиме јасни граници меѓу минатото, сегашноста и иднината - живееме во време на симултаноста - „во епоха на јукстапозицијата, епоха на блиското и далечното, на едно-до-друго, на распрснатото." 20 Животот, во овој модел, не е едноставно пат што се протега во иднината, туку мрежа од односи, точки, крстосници - овој концепт на времето и местото е произведен од различни идеологии и различни сфаќања на субјективноста, во која единствениот поим за индивидуата и нејзините слободи нема смисла, бидејќи слободата на едно место предизвикува неслобода на друго. Рентоновото легендарно отфрлање на малограѓанскиот живот во претходно цитираниот говор, на пример, изразува таков модел на време и место, избор и угнетеност. Тој го препознава лажното ветување за индивидуално здравје и среќа на начин на кој индивидуалните слободи покриваат многу систематски начини на угнетување.

Фуко ја дефинира хетеротопијата, упатувајќи на некои специјални простори што „имаат чудно својство да бидат во врска со сите други места." Таквите хетеротопски места функционираат „било за да им се спротивствуваат, да ги неутрализираат, да ги одразуваат или да ги пресвртуваат" оние места до кои се наоѓаат. Како примери, тој ги наведува: огледалата (место кое не само што одразува, претставува или прекршува); интернатите (место каде што кризата и трансформирањето се прават преку дисциплинирачко управување); лудниците/затворите (места за одделување на девијантните индивидуи од нормативната популација). ${ }^{21}$ Со други зборови, хетеротопски се или илузорните светови што ги разоткриваат „реалните“ простори како уште поилузорни (борделот ја разоткрива нереалноста на хетеросексуалниот брак; лудницата ги открива неуспесите на граѓанското општество); или периферните простори што функционираат како компензирачки простори што ги прибираат неуспесите на "нормативниот" простор (колонијата е of "heterotopia" as an alternative history of space. Foucault maps a conventional model of history within which the past represents the space of the dead and the future represents the space of possibility. He argues however that we can no longer make clean breaks between past, present and future - we live in an age of simultaneity - "an epoch of juxtaposition, the epoch of the near and far, of the side-by-side, of the dispersed."20 Life, within this model, is not simply a road stretching into the future but a network of relations, points, intersections - such a concept of time and space is produced by different ideologies and different notions of subjectivity within which a unitary notion of the individual and his freedoms makes no sense since freedom in one place always entails unfreedom in another. Renton's fabulous rejection of bourgeois life, for example, in the speech quoted above articulates just such a model of time and space, choice and oppression. He recognizes the false promise of individual health and happiness and the ways in which individual freedoms cover over much more systematic modes of oppression.

Foucault defines heterotopia with reference to certain special spaces that "have the curious property of being in relation with all other sites." Such heterotopic sites function "either in order to contradict, neutralize, mirror or invert" the sites they juxtapose. And he lists as examples: mirrors (a place that neither simply reflects, represents nor refracts); boarding schools (a place where crisis and transition is managed through disciplinary regimes); asylums/prisons (places to separate out deviant individuals from the normative population). ${ }^{21}$ In other words, heterotopia are either illusionary spaces that expose "real" spaces as even more illusionary (the brothel exposes the unreality of heterosexual marriage; the asylum reveals the failures of civil society); or peripheral places which function as compensatory sites which accommodate the failures of "normative" space (the colony as compensatory site for the nation state; the prison as compensatory site for the criminal justice system). 
компензирачки простор за националната држава; затворот е компензирачки простор за правниот систем).

За нашата цел е интересно тоа што Фуко и возот го опишува како хетеротопски простор. Тој пишува: „возот е исклучителен врзоп од релации, затоа што е нешто низ кое некој поминува, тој е и нешто со што некој може да стигне од едно место во друго, а тој е и нешто што нѐ одминува..." Во Trainspotting возот меѓ Лондон и Единбург е хетеротопски простор што поврзува два града, два главни града, два омилени туристички града, но тој попатно запира и ја исцртува релацијата меѓу Лондон, Единбург и сите места меѓу нив. Бегби и Рентон заедно се возат во воз, со катастрофални резултати, во поглавјето наречено "Inter Shitty". Насловот е шега за односите меѓу времето, просторот и транспортот, со тоа што "city" го менува во "shitty", па надворешното патување низ земјата го претвора во внатрешно патување низ дебелото црево.

Bo "Trainspotting", Велч за „внатрешното" повеќепатти зборува, не како за психичко, туку како за стомачно; и целиот дискурс во неговиот роман се врти околу телото како хетеротопски простор за конзумација и создавање измет, урина и блујаници.

"Inter Shitty" е раскажано преку споулавената свест на Бегби, кој во романот го претставува гласот на жестокото и сурово насилство, како и она што ќе биде наречено „фашизам“ во книгата. Неговите прекари, Франко и Генералисимо, силно го поврзуваат со насилството на апсолутистичкото владеење. Додека Рентон и Бегби седат во возот и пијат, Бегби коментира дека возот не треба да запре никаде меѓу Единбург и Лондон: „треба да биде Единбург до Лондон, крај на причата, да ја ебам“ (113). Во неговата апсолутистичка рамка, за него постојат само две места - таму каде што е и таму каде што треба да стигне, сите други места се непотребни "shitties." Како и обично, Бегби започнува тепачка во возот. Бесен е поради тоа што тој и неговите другари не можат да ги користат многуте празни седишта, бидејќи тие се резервирани за другите патници што треба да се качат во возот во другите
Interestingly enough for our purposes, Foucault also describes the train as a heterotopic space. He writes: "a train is an extraordinary bundle of relations because it is something through which one goes, it is also something by means of which one can go from one point to another, and then it is also something that goes by..." In Trainspotting, the train between London and Edinburgh is a heterotopic space which connects two sites, two capitals, two tourist havens but which also stops along the way and maps a relations between London, Edinburgh and all the places in between. Begbie and Renton take the train together and with disastrous results in a chapter called "Inter Shitty." This title makes a joke out of the relations between time, space and transport by folding city into "shitty" which makes an external journey across the country into an internal journey through the bowels.

Welch repeatedly refers to the "internal" in Trainspotting as not psychic but intestinal; and all the discourse on inner life in this novel revolves around the body as a heterotopic space for consumption and production of shit and "pish" and vomit.

"Inter Shitty" is told through the rabid consciousness of Begbie who constitutes the voice of outrage and raw violence in the novel as well as what gets called "fascism" in the book. His nicknames, "Franco" and "Generalissimo" pointedly link him with the violence of authoritarian rule. As Renton and Begbie sit on the train drinking, Begbie comments that the train should not stop anywhere between Edinburgh and London: "it should jist be Edinburgh to London, end ay fucking story" (113). Within his authoritarian framework, only two places exist for him - where he is and where he is going, all other places are useless "shitties." Begbie, as usual, begins a fight on the train. He becomes enraged by the fact that many empty seats cannot be occupied by him or his mates because they are reserved for other travelers due to board the train in other cities. Begbie calls the reservation system a "fucking liberty" (114) and continues in his own unique and horrifying voice about the class politics of the train: 
градови. Системот на резервации Бегби го нарекува „ебена слобода" (144) и со својот специфичен застрашувачки глас продолжува да зборува за класната политика на возот. „Ау, ги резервирале местата. Ебена слобода, тоа ти е. А требе - кој прв си дошол, тој да си седне. Глупа резервација на местата... ќе им дадам на пиздите резервирани места, да ги ебам" (114) Тука Бегби е обележан и како особено зол насилник и како груб, но релевантен критичар на малограѓанската респектибилност. Неговите анализи всушност ја откриваат буржуаската смисла за овластување, со која некој може да завземе место без да биде во него.

Насловот на романот, "Trainspotting", го зел името од безопасната детска игра на забележување возови во гратчињата низ Велика Британија. Фројд пишува за момчешката фасцинација од возовите како за сексуална фасцинација со особеното движење и со „возбудата поради движењето“ што ја донесува возењето. Фројд пишува: „Збунувачки е фактот што момчињата толку исклучително интензивно се интересираат за сите нешта поврзани со железницата, па на возраст кога продукцијата на фантазиите е најактивна (непосредно пред пубертетот), ги употребуваат овие нешта како јадро на симболиката што е особено сексуална."22 За момчињата, според Фројд, возот е претстава и за фалусниот симбол и за движењето на самата сексуална активност. На тој начин активноста на забележување возови станува помалку асексуално хоби, а повеќе автоеротска или хомоеротска активност. Така, средбата меѓу Бегби и неговиот татко на местото каде што порано била старата ЦЦентрална станица на Леит, станува позначајна, кога стариот им вели на Бегби и момчињата: „Шо прајте 6е, дечки? Глеате возови, а?“ Бегби го отфрла својот пијан, паднат татко, тука на местото на машкото сексуално будење, нарекувајќи го „ебена стара пизда“ и си оди. Отфрлањето на таткото е повеќе од едноставно решавање на едиповиот комплекс; тоа на повеќе начини претставува отфрлање на самата маш-ка сексуалност. Малкумина од момчињата во романот се впуштаат во каков и да е облик на „успешен“ сексуален однос и во најголемиот дел од времето повеќе ги интересира пиењето и дрогирањето отколку сексот. Пустата станица во
"Aw they booked seats. Fuckin liberty, so it is. It should be first fuckin come, first fuckin served. Aw this bookin seats shite...ah'll give the cunts bookin fuckin seats" (114). Here Begbie is marked as both a particularly vicious bully and as a harsh but relevant critic of bourgeois respectability. His analysis actually reveals the privilege of a bourgeois sense of entitlement whereby one can take up space without even being in it.

The novel's title, Trainspotting, takes its name from the harmless boyhood occupation of watching for trains in small towns across Great Britain. Freud writes about the fascination that trains hold for boys as a sexual fascination with the particular motion and "sensations of movement" brought on by the train ride. Freud writes: "It is a puzzling fact that boys take such an extraordinarily intense interest in all things connected with railways, and at the age at which the production of phantasies is most active (shortly before puberty), use those things as the nucleus of a symbolism which is particularly sexual."22 For boys, according to Freud, the train represents both a phallic symbol and the motion of sexual activity itself. The activity of "trainspotting" then becomes less of an asexual hobby and more of an autoerotic or homoerotic activity. An encounter between Begbie and his father at the site where the old "Central Station" of Leith used to be, becomes all the more relevant then, when the old man says to Begbie and his mates: "What yis up tae lads? Trainspotting, eh?" Begbie rejects his drunken and down and out father here at the site of male sexual awakening calling him a "fucking auld cunt" and striding away. The rejection of the father is more than simply the resolution of an oedipal complex; in many ways, it represents the rejection of male sexuality itself. Few of the Skag Lads in the novel engage in any form of "successful" sexual interaction and most of the time they are more interested in drinking of doing drugs than in sex. The deserted station at Leith, haunted as it is by the ghost of Begbie's father and the lost past of male sexual promise, represents now the break down of male lines of authority and inheritance; the disintegration of phallic power and the end of trainspotting. 
Леит, запоседната од духот на таткото на Бегби и изгубеното минато на машкото сексуално ветување, сега го претставува кршењето на машките линии на авторитет и наследство, дезинтеграцијата на фалусната моќ и крајот на забележувањето возови.

"Trainspotting" е само еден од низата британски филмови и романи што се населуваат во свеста на насилникот за да й дозволат „на империјата да го возврати ударот". Освен тоа, не треба да нѐ изненади тоа што кога империјата ќе одговори, тоа ќe го стори во форма на Калибановото проклетство: валкано со жаргонски говор, обоено со злоба и бес. Иако "Trainspotting" сака да ја погоди респектибилната мажественост со тоа што го отфрла домаќинството и горчливо ги критикува доминантните форми на мажественоста отелотворени во војникот, полицаецот, бизнисменот и таткото, овој роман ги вкотвува новите форми на мажественост на насилни и бунтовни мажи, научени на хомофобија, расизам и сексизам и обучени да убиваат. Конечно, "Trainspotting" ја искажува мажественоста на помалите групи, која е врзана со доминантната мажественост, така што го претставува спротивното; оваа спротивност на мажественоста, сепак, не може да ја признае можноста мажественоста да биде искована од машки и женски тела. Меѓутоа, еден друг постимперијален текст за мажественоста, Како од мајка родени, режиран од Питер Катанео, целосно ја истражува можноста да се опише понижувањето и понизноста, без да се окривуваат жените за тоа и без да претставува опаѓање на машката сила како резултат на подемот на корозивната и кастрирачка форма на женската моќ.

Како од мајка родени, во кој игра Роберт Карлајл (кој го играше страшниот, но смешен Бегби во Возовите минуваат) се случува по падот на индустријата за челик во Шефилд. Филмот започнува со краток документарец, журнал, за Шефилдовиот челик во раните 70-ти. Филмот почнува дваесет години подоцна, кога челичарницата е затворена и илјадници работници се без работа. Во овој филм, челикот функционира како метафора за старите
Trainspotting is just one of a handful of new British films and novels which inhabit the consciousness of the thug in order to allow the "empire to speak back." We should not be surprised, moreover, that when the empire does reply it is in the form of Caliban's curse: filthy and slang-laden, colored by spite and rage. While Trainspotting takes aim at respectable masculinity by refusing domestic manhood and bitterly critiquing the dominant forms of masculinity embodied in the soldier, the police man, the business man and the father, it still anchors its new forms of masculinity to violent and unruly males, schooled in homophobia, racism and sexism and licensed to kill. Trainspotting ultimately, articulates a minority masculinity that is bound to dominant masculinity by virtue of representing its opposite; this counter-masculinity still cannot acknowledge the possibility of a masculinity forged from gay and female bodies. Another postimperial masculinity text, however, The Full Monty, directed by Peter Cattaneo, fully explores the possibility of depicting male humiliation and humility without blaming women and without representing a decline of masculine strength as the result of the rise of a corrosive and castrating form of feminine power.

The Full Monty, starring Robert Carlyle (who played the terrifying but humorous Begbie in Trainspotting) takes place in the aftermath of the decline of Sheffield's steel industry. The film opens with a short documentary, a public service film, which recounts the glory of Sheffield's steel works in the early 1970's. The film begins some 20 years later when the steel works have closed and thousands of steel workers are unemployed. Steel, in this film, work as a metaphor for past models of masculinity, 
модели на мажественост, онаа мажественост што зависела од "цврстото тело", да го употребам терминот на Сузан Џефорд, но падот на челичарницата служи и како мрачен потсетник за беснеењето на тачеризмот во британската национална индустрија. ${ }^{23}$ Многу мажи во Шефилд се без работа, додека нивните девојки, жени и мајки кои работат во услужните дејности, сѐ уште се вработени. Економските несразмерности меѓу физичките работници кои сега се невработени и физичките работнички кои си ги задржале вработувањата значајно и неотповикливо ги поместиле координатите и значењата на родот и сексуалноста. Кога во градот ќе дојде едно кабаре, некои од локалните момчиња ќе решат дека треба да се обидат да заработат некој денар со стриптиз и еротско танцување. За чудо, процесот на развивање на шоуто ги фрла мажите во низа дилеми кои се појавиле за да ја дефинираат женственоста и кои речиси никогаш не ги поврзуваме со мажественоста: мажите се грижат за своите тела, облеката, способноста да танцуваат, пожелноста.

Филмот почнува со серија напади врз машките привилегии: протагонистот Газ е невработен и се мачи да ѝ плаќa алиментација на поранешната жена за да го одржи односот со синот. Другар му Дејв, според зборовите на жена му, „се предал", се ограничил на социјална помош и си седи дома. Џералд, поранешниот шеф на Газ и Дејв, не може да се натера себеси да й каже на жена си дека ја загубил работата, па секое утро тргнува на работа и оди во Заводот за вработување, очајнички надевајќ се дека ḱе најде работа пред таа да дознае дека ги потрошиле парите. Конвенционалните машки улоги на татко, маж и хранител се под сериозен притисок кога почнува филмот а мажественоста уште од почеток е дефинирана како категорија на која од сите страни иे се заканува редундантHOCT.

Додека еден ден Газ и Дејв се враќаат дома по тешкиот ден поминат во крадење остатоци метал од старата фабрика, тие среќаваат долга редица жени кои чекаат да бидат примени во клубот „Работници“, каде што настапуваат кабаретските танчери. Газ преку прозорецот masculinities dependent upon "hard bodies" to use Susan Jefford's term but, the decline of the steel works also serves as a grim reminder of the ravages of Thatcherism on British nationalized industry. ${ }^{23}$ Many men in Sheffield are out of work while their girlfriends, wives and mothers who work in the service industry still have jobs. The economic disparities between the blue collar men who are now unemployed and the blue collar women who retain their service jobs shifts significantly and irrevocably the coordinates and meanings of gender and sexuality. When a Chippendale's show comes to town, some of the local lads decide that they should try and make some money by stripping and erotic dancing. Amazingly, the process of developing a show throws the men into a series of dilemmas which we almost never associate with masculinity but which have come to define femininity: the men worry about their bodies, their clothes, their ability to dance, their desirability.

The film opens with a series of assaults upon male privilege: the film's protoganist, Gaz, is unemployed and struggling to make custody payments to his ex-wife in order to maintain a relationship with his son. Dave, his mate, has, in the words of his wife, "given up" and resigned himself to redundancy at work and at home. Gerald, the former boss of Gaz and Dave, cannot bring himself to tell his wife that he is out of work, so he leaves for work every morning and heads to the job center, desperately hoping to find work before she finds out that their money has run out. The conventional masculine roles of father, husband and breadwinner are all under serious pressure as the film begins and masculinity is defined from the outset as a category threatened on all sides by redundancy.

As Gaz and Dave return home one day after a hard day of stealing scrap metal from the old factory, they encounter a long line of women waiting to be admitted to the Working Men's Club where the Chippendale dancers are performing. Gaz slips into the men's bathroom through a window to survey 
се вовира во машкиот тоалет за оттаму да ја гледа сцената наменета "само за жени". Но, пред да добие вистинска шанса да ја гледа величествената сцена во која стотици жени викаат и скокаат по стриптизерот, три жени одат кон машкиот тоалет за да ја избегнат редицата пред женскиот. Газ се протнува во една преграда и гледа низ дупката од вратата. Додека Газ тука е во позиција што се чини дека е традиционално машка, позиција на воајер, она што го гледа радикално ги менува родовите улоги на гледачите. Газ најпрвин е задоволен од тоа што ги гледа жените како машкиот тоалет го претвораат во женски ставајки шминка пред огледалото. Ги гледа нив како се гледаат себеси. Сепак, пред негови очи, сцената нагло се менува од женска сцена на изложеност, кон машка сцена на активност, кога една од жените го подигнува здолништето и стоејќи уринира во писоарот на задоволство на пријателките. Место да се ограничи едноставно на психоаналитичкиот модел на кастрација или женски фалицизам, оваа сцена, според мене, регистрира отфрлање на неколку сфаќања за родовите: прво, одбива да ја обележи машкоста како место на сексуализиран воајеризам, а второ, оваа сцена ги сугерира ефектите на дури и случајната инвазија на машкиот свет од страна на жените. Конечно, рамката на кадарот - што го лоцира мажот којшто се крие зад вратата, двете жени пред огледалото и онаа пред писоарот - ја предвидува темата на погледот што ке биде елаборирана во филмот и ќе кулминира во последната слика.

Растечката редундантност на старите облици на родови релации и старите облици на мажественост е потцртана во Како од мајка родени со оваа нагла, но неповратна реконфигурација на машкиот поглед. Во холивудскиот филм, машкиот поглед го структурира погледот на гледачот и на машкиот гледач му овозможува да се идентификува со активноста во сцената и да ја посакува жената што е поставена како објект на неговиот поглед/жел6а. Мажествената жена во оваа сцена, жената пред писоарот, го реструктуира машкиот поглед со тоа што инсистира машкиот поглед да биде разбиено преку алтернативните начини на мажественост. Значи, во сцената во машкиот тоалет, Газ може воајеристички да sирка во the "women only" scene inside. But before he has a real chance to take in the glorious scene of hundreds of women yelling and whooping at a male stripper, three women make their way towards the men's room hoping to avoid a line for the toilet. Gaz slips into a stall and watches what transpires through a hole in the door. While Gaz here occupies the seemingly traditional male position of the voyeur or peeping tom, what he sees changes radically the gendered roies of spectatorship. At first, Gaz takes pleasure in watching the women transform the men's room into a women's room by applying make-up in the mirror. He watches them watching themselves. Right before his eyes, however, the scene changes abruptly from a feminine scene of display to a masculine scene of activity when one of the women hikes up her skirt and pees standing up at the urinal to the delight of her friends. Rather than conforming to simply a psychoanalytic model of either castration or female phallicism, this scene, I think, registers a refusal of several gender logics: first it refuses to mark maleness as the place of sexualized voyeurism, and second, the scene suggests the effects of even casual invasions of male space by women. Finally, the framing of the shot--which locates a man hiding behind a door, two women in front of a mirror and another woman at a urinal--predicts the politics of the gaze that will be elaborated in the film and will culminate in the film's final shot.

The growing redundancy of old forms of gender relations and old forms of masculinity is underscored in The Full Monty by this abrupt but irreversible reconfiguration of the male gaze. In Hollywood cinema, the male gaze structures the look of the viewer and allows for the male spectator to identify with activity in the scene and to desire the female who is positioned as the object of his gaze/desire. The masculine woman in this scene, the woman at the urinal, restructures the male gaze by insisting that the male gaze be routed through alternative modes of masculinity. In the men's room scene, then, Gaz can peer voyeuristically at the women in the mirror only if he also looks at the woman at the urinal. Gaz's struggle, here and in other key scenes of watching and being watched, indicates how thoroughly 
жената пред огледалото, само ако гледа и во жената пред писоарот. Газовата борба, тука и во другите клучни сцени на гледање и примање погледи, покажува колку длабоко се трансформирани односите меѓу мажите и жените, поради промените на ниво на економијата и работењето. Сепак, би било несоодветно да кажеме дека недостигот од економска моќ применет од мажите од работничката класа од Шефилд „ги кастрира“. Наместо тоа, им дозволува да се видат себеси како субјекти што го претставуваат и го симболизираат недостигот, наместо така да ги гледаат жените.

Кога Газ ќе им каже на своите пријатели во Заводот за вработување што видел во машкиот тоалет, нивните одговори бележат непознати форми на машка параноја што се предизвикани помалку од бесот спрема жените, а повеќе од чувството на неизбежно изобилство на хетеронормативна машкост штом мажественоста циркулира низ различни тела. Газ сугерира: „Кога жените ќе почнат да мочаат како нас, толку е, готови сме Дејв, екстинкто." Друг маж додава: „Тие се претвораат во нас... за четири години мажите нема да постојат, освен во зоолошки градини, неупотребливи, диносауруси, застарени... како скејтбордите." Оваа тема на машко себепотценување ја достига својата најниска точка кога Дејв и Газ наоѓаат маж што сака да се убие во својот автомобил. Спасувањето и враќањето во живот на овој самоубиец, Лампер, е несентиментално, а сепак кондензира силна блискост меѓу мажите во неволја. Братимењето ги надминува класните граници кога момчињата го земаат својот поранешен шеф Џералд да им биде инструктор. Неговите балски танчерски способности, некогашни белези на рафинираната и респектабилна мажественост, сега стануваат основа на новото машко заедништво, инспирирано од разочараноста и отфрленоста, но се продуктивни за создавање нов модел на мажевност центриран врз машката изложеност и ранливост.

Танчерското братство станува побројно кога Газ и неговите пријатели прават аудиции за новата стриптизерска трупа и наоѓаaт уште двајца членови: црнецот со male-female relations have been transformed by changes at the level of economy and labor practices. It would be inaccurate however to say that the lack of economic power exercised by the working class men of Sheffield "castrates" them; rather, it allows them to see themselves, rather than women, as the subjects who represent and figure lack.

When Gaz reports back to his friends at the unemployment office about what he has witnessed in the men's room, their responses record unfamiliar forms of male paranoia which are inflected less by rage at women and more by a sense of the impending redundancy of heteronormative maleness once masculinity circulates through different bodies. Gaz himself suggests: "When women start pissing like us, that's it, we're finished Dave, extincto." Another man adds: "They're turning into us...in four years men won't exist except in zoos, obsolete, dinosaurs, yesterday's news...like skateboards." This theme of male self-deprecation reaches its nadir when Dave and Gaz find a man trying to kill himself in his car. The rescue and resuscitation of the suicidal character, Lamper, is unsentimental and yet it precipitates a strong fraternity between men in trouble. The fraternity crosses class lines when the lads recruit their former foreman Gerald to be their dance instructor. His ballroom dance skills, once the mark of a refined and respectable masculinity, now become the basis for a new male collectivity inspired by disenchantment and exclusion but productive of a new model of maleness centered upon masculine display and vulnerability.

The dance fraternity grows in numbers when Gaz and his new friends begin auditions for their stripper troupe and they find two more members: a black man named Horse and a 
прекар Коњ и хомосексуалецот Гај. Како од мајка родени алудира на алтернативните конструкции на мажественоста и преку овие ликови ги поврзува со расата и сексуалноста. Ликот на Коњот, покрај неговото име, успева да се издигне над стереотипот на црнечката мажественост поврзана со големиот фалус, а токму хомосексуалецот, наречен со општото име Гај, ја презема улогата на алфамажјак во групата. Уште повеќе, кога Гај започнува врска со Лампер, нивните алтернативни верзии на мажественоста само ги уверуваат другите дека доминантната мажественост (како умирачката индустрија на челикот) е тотално банкротирана форма.

Филмов конечно сугерира дека кога мажите и жените општествено, финансиски, па дури и културолошки, ке си ги променат улогите, ефектите не се толку лоши. Жените со моќ, откриваме, не се однесуваат едноставно како мажи, туку ги култивираат своите односи спрема мажественоста и женственоста и ги охрабруваат мажите околу себе да го сторат истото. Слично, мажите на кои им е одземена моќта, лесно паѓаат во конвенционалните грижи околу импотентноста, но ги учат и лекциите на објектификацијата. Во многу комичната сцена дома кај Џералд, каде што мажите за првпат се обидуваат да се соблечат еден пред друг, се појавува цела низа проблеми во врска со телото. Кога Дејв ке признае дека се чувствува дебел и несмасен, Џералд му одвраќа: „Дебелината е женска работа, знаеш." Потоа мажите на Дејв и еден на друг си даваат совети за држење диета и вежбање. Тоа што сценава се одигрува раскошна вила, приградски дом на поранешниот функционер, исто така ги прераспределува класните разлики во групата и односите меѓу мажите и домаќинството. Како што наоѓаме жени во машкиот тоалет во клубот „Работници", така наоѓаме мажи дома, ден-ски, кои дискутираат за телата.

Крајната сцена сугерира како новите концепти на мажественоста можат и навистина треба да бидат разбиени преку феминизмот и женското тело. Газ краде примерок на филмот Флешденс за да им покаже на танчерите пример за тоа како треба да изгледа танцувањето. Но gay man named Guy. The Full Monty hints at alternative constructions of masculinity and associates them through these characters with race and sexuality. The character of Horse, despite his name, manages to rise above the stereotype of a black masculinity anchored by a huge phallus and it is the gay man, generically called Guy, who assumes the role of alpha male in the group. Furthermore, when Guy begins a relationship with Lamper, their alternative versions of masculinity only persuade the other men that dominant masculinity (like the dying steel industry) is a totally bankrupt form.

The film ultimately suggests that when men and women reverse places socially, financially and even culturally, the effects are not all bad. Women with power, we discover, do not simply behave like men, they cultivate their own relations to masculinity and femininity and they encourage the men around them to do the same. Similarly, disempowered men may easily fall into conventional concerns about impotence, but they also learn lessons in objectification. In a hilarious scene at Gerald's where the men first try stripping in front of each other, a whole array of issues come up about embodiment. When Dave confesses that he feels fat and out of shape, Gerald shoots back: "Fat is a feminist issue you know." The men proceed to give Dave and each other advice about dieting and working out. The fact that this scene takes place in the 'posh' suburban home of the former foreman also recalculates the class differentials within the group and the relationships between men and domesticity. Just as we found women in the men's room at the working man's club, so we find men at home during the day discussing body issues.

One final scene suggests how new conceptions of masculinity can and indeed must be routed through feminism and the female body. Gaz steals a copy of Flashdance in order to give his dancers some sense of what good dancing should look like. But as the film begins, Dave peers at the screen in wonder 
кога ќе почне филмот, Дејв зјапа во екранот чудејќи се поради почетната сцена кога Џенифер Билс, ноќна танчерка, денски заварува во фабриката. Глетката на женска танчерка како заварувач, како и сликата на жената пред писоарот, уште еднаш ја предизвикуваат идејата за жената како изложен предмет, но креираат и неприродна слика на женска мажественост, што мажите сега ќе мора да ја достигнат. Мажественоста низ целиот филм Како од мајка родени е прецизно заварена форма на заедништвото на мажественостите на помалите групи. Конечно, овој филм за мажите под притисок креира нови стандарди за опишување на мажественоста во водечките филмови, а завршува со табуизираната претстава на машката голотија. Во својата конечна успешност, оваа британска комедија открива дека мажественоста на помалите групи може да ја прикаже водечката мажественост како опасен мит за потентноста, неранливоста и насилството. Последната слика што треба да ја сочини главната финта на соблекувањето, всушност одбива да го открие фалусот при тоталитетот на машкоста; финалето на машкиот стриптиз е сликано од зад сцената и статичниот кадар ги фаќа шестемина мажи одзади и целата толпа жени што врескаат. Така, целосниот приказ е овој кадар што ја вклучува жената како воајер, а машкото тело е изложено, а според формата и содржината тој е одек на поранешната сцена со жената пред писоарот. Во обете сцени го гледаме само фалусниот субјект одзади и во обете сцени погледот на машкиот воајер е извлечено преку погледот на жената. Двете сцени заедно го сочинуваат "the full monty".

\section{3. Кралеви и чудаци: Заклучок}

Би сакала да завршам така што ќе го исполнам ветувањето од мојот наслов и многу накратко ќе се осврнам врз империјалната мажественост на женскиот травестит. Иако Како од мајка родени ја замислува можноста жената да ја употреби и да ја отелотвори мажественоста, овој филм се задоволува со тоа ваквата примена да ја опише на начин на полово пресвртување. Во мојот заклучок, сугерирам дека изведбите на женските травестити прават повеќе од имитирање на машката мажественост at the film's opening scene of Jennifer Beals, dancer by night, welding by day in a factory. The spectacle of the female dancer as welder, like the image of the woman at the urinal, challenges once more the idea of woman as an object of display but also creates the uncanny image of a female masculinity that the men must now emulate. Masculinity throughout The Full Monty is precisely welded together from a collectivity of minority masculinities. This film, finally, about men under pressure creates new standards for the depiction of masculinity in mainstream film and it ends by referencing the taboo representation of male nudity. In its final flourish, this British comedy reveals that minority masculinities can expose mainstream masculinity as a dangerous myth of potency, invulnerability and violence. The final shot which should constitute the "money shot" of "the full monty" actually refuses to make the visibility of the phallus into the totality of maleness; the finale of the strip show is filmed from the back of the stage and a freeze frame captures the six naked men from behind and the crowd of screaming women full on. The full monty then is this shot which includes the female voyeur looking and the male body on display and it echoes in form and content the earlier shot of the woman at the urinal. In both scenes, we only see the phallic subject from behind and in both scenes the gaze of the male voyeur is routed through the gaze of women. The two scenes together make up the full monty.

\section{Kings and Geezers: A Conclusion}

l'd like to end by fulfilling the promise of my title and referencing very briefly the post imperial masculinity of the drag king. While The Full Monty imagines the possibility of women deploying and embodying masculinity, it was content to depict such deployments in the mode of sex reversals. In this my conclusion, I suggest how drag king performances do more than imitate male masculinity or deploy the signifiers of dominant masculinity from a recognizably female position. Rather drag king masculinities remind us that masculinity is 
или од употребување на означителите на доминантната мажественост од препознатлива женска позиција. Мажественостите на овие травестити не потсетуваат дека мажественоста најдобро се проучува во оние изведбени арени каде што целосно го напушта машкото тело.

Вечерта кога бев во клубот "Чудаци“ во Лондон, имаше барем 300 необични лица во преполнетиот клуб. Лезбејки, педери, хетеросексуални, транссексуални, трансродови лица, сите тие се расфрлуваа со жива мешаница од мустаќи, козји брадички, бакенбарди, брадишта, костуми, вратоврски, кожени јакни и работнички униформи. Темата, се разбира, беше „чудаци“, па беше предвидливо тоа што во текот на вечерта се одржа „натпревар на чудаци", за да им се доделат награди на најдобрите чудаци од толпата. На натпреварот на чудаците се појавија низа комичари од типот на Бени Хил, имитатори на Лијам Галагер од „Оејзис“ кои отвораа уста како да пеат, а имаше и стриптиз во кој травеститот ќе соблечеше едно парче облека за да открие дека под него има друго и една сцена од филм со Џемс Бонд. "Gezeer" („чудак"), се разбира, се однесува на посебен британски вид мажественост што горедолу одговара на она што во американскиот сленг е "a man's man". Клубскиот изведувач Џулс, женски травестит во стилот на "gezeer", го дефинира зборот "gezeer" како „дрзок шизик кој е полн со самодоверба и малку преблескав." Травеститот-изведувач Стенли ја проширува оваа дефиниција: „Мислам дека "gezeer" се однесува на особено одвратната момчешка британска мажественост“. Некои од помажествените женски травестити во интервјуата сугерираат дека травестијата им дава простор да флертуваат со екстремните верзии на мажественоста, но и да ги прекршат суштинските врски мегу мажественоста и машкоста. Џулс објаснува дека шоуто на чудаци, на пример, било можност да се изрази еден особен облик на машкост. Џулс вели: „Најголемиот дел од чудаците се мажи, некои се жени, некои се женски травестити. Но, тоа е една од оние машки улоги што е целосно одвоена од идентитетот."

Токму преку перформансот на „момчешките“ облици на мажественост што ни беа откриени во Меѓу силеџи- best studied in those performative arenas where it leaves the male body altogether.

On the night that $I$ attended Club Geezer in London there were at least 300 queer people in a crowded pub. Lesbians, gay men, straight people, transsexuals and transgender people all sported a lively mix of mustaches, goatees, sideburns, full beards, suits, ties, leather daddy gear, and construction uniforms. The theme, of course, was "geezer," and the evening predictably led up to a "Geezer Contest" to award prizes to the best geezers in the crowd. The Geezer contest featured an array of Benny Hill type stand up comics, a lip-synching impersonation of Liam Gallagher from Oasis, a strip act within which a king stripped off one layer clothes to reveal yet another layer and a scene from a James Bond film. Geezer, of course, references a peculiarly British brand of masculinity that may loosely translate in American vernacular as "a man's man." Club performer Jewels, himself a geezer-style drag king, defines geezer as "a cocky wide-boy who's full of confidence and a bit too flash." Drag king performer Stanley elaborates on this definition: "I think geezer references a particularly repulsive laddish English masculinity." Some of the butch drag kings suggested in interviews that the drag king space gives them room to flirt with excessive versions of masculinity but also to break down the essential connections between masculinity and maleness. Jewels explains that the Geezer show, for example, was an opportunity to take on a particularly crude form of masculinity. Jewels says: "Most geezers are men, some are women, some are drag kings. But it is one of those masculine roles that is completely divorced from identity."

By performing precisely the "laddish" forms of masculinity that were so reviled in Among the Thugs, the drag king 
ите, шоуто на женските травестити ни обрнува внимание на склоностите на силеџиската мажественост и на подмолната конструкција на силеџијата во имагинацијата на луѓето. Преку форма на симпатична пародија чудацитетравестити ги прават видливи начините на кои мажите од работничката класа се претвораат во ризница за најблескавите неуспеси на воопштената машка мажественост. Како и мажите во Како од мајка родени, женските травестити ги употребуваат перформансите и машката изложеност за да ги одвојат: мажественоста од машкоста, машкоста од фалусната моќ и фалусната моќ од општествениот легитимитет.

Овој текст ги компарираше некои одбрани модерни и постмодерни, империјални и постимперијални форми на мажественост и тврдеше дека времето е пред нас за да направиме сеопфатна реартикулација на машките норми. Особените конфигурации на класата, расата и сексуалноста во постколнијалната Британија допуштаат колекција исклучителни претстави на фрагилни и ранливи мажествености. Во Како од мајка родени моќта на женскиот поглед го разнишува митот за машката самодоволност и машката совршеност, па инсистира на нова форма на мажественост што е силна и задоволувачка без да се потпира на конвенционалните облици на мизогинија. Во "Trainspotting" момчињата уживаат во својот простотилак и од принцип ја отфрлаат респектибилноста на идеалниот машки род; а женските травестити во клубот "Чудаци“ ни ги предочуваат најперформативните аспекти на машката мажественост преку нивните сопствени женски мажествености. Како што влегуваме во новиот век, ниските облици на мажественоста од кои толку се плашат машките модернисти - меѓу нив и хомосексуалците и мажествените жени - ни дошле за да ја дефинираат милениумската мажественост. Елиотовата кошмарна визија на апокалипсата на крајот од „Шупливите мажи", може навистина да биде музика за нов почеток: „Ова е начинот на кој настанува крај на светот, ова е начинот на кој настанува крај на светот, ова е начинот на кој настанува крај на светот, не со тресок, но со плач."

Превод: Василка Пемова show draws our attention to both the liabilities of thuggish masculinity and the insidious construction of the thug in the popular imagination. Through a form of loving parody, the drag king geezers make visible how the working class man has been turned into a repository for the most glaring failures of male masculinity in general. Like the men in The Full Monty, the drag kings deploy performance and masculine display to unhinge masculinity from maleness, maleness from phallic power and phallic power from social legitimacy.

This paper has compared some select modern and postmodern, imperial and post imperial forms of masculinity and argued that the time is upon us for a thorough going rearticulation of masculine norms. The particular configurations of class and race and sexuality in post-colonial Britain allow for a range of extraordinary representations of fragile and vulnerable masculinities. In The Full Monty the power of the female gaze shatters the myth of male self-sufficiency and male perfection, and insists upon a new form of masculinity that is powerful and pleasurable without relying upon conventional modes of misogyny. In Trainspotting the Skag lads revel in their abjection and refuse outright the respectability of ideal manhood; and the drag kings at Club Geezer relay the most performative aspects of male masculinity through their own female masculinities. As we enter a new century, the abject forms of masculinity so feared by male modernists--the gay man and the virile woman among others--have come to define millennial masculinity. Eliot's nightmare vision of apocalypse at the close of "Hollow Men," may indeed be the soundtrack to a new beginning: "This is the way the world ends, This is the way the world ends, this is the way the world ends, not with a bang but a whimper." 


\section{БЕЛЕШКИ}

1 Лиза Лоу пишувала за односите меѓу доминантните и малцинските култури како за "нестабилни и незавршени". Во еден многу корисен израз на динамичкото движење на хегемонијата, Лоу пишува: "Би можеле да кажеме дека хегемонијата не е само политички процес преку кој одредена група се конституира себеси како вистинската или мнозинската, а во односот со неа малцинствата се дефинираат и се познаваат себеси како другите, туку е и процес со кој различните и неспоредливи позиции на другоста можат да се здружат и да сочинат ново мнозинство, спротивно на хегемонијата. Lisa Lowe, Immigrant Acts: On Asian American Cultural Polotics (Durham, NC: Duke UP, 1996): 69.

2 На пат за Лондон во летото, 1990, бев изненадена кога открив дека весниците се полни со прилози за очигледниот голем замав на кризата на мажественоста. The Sunday Observer Magazine, на пример, на својата насловна страница имаше слика на голо машко бебе со наслов: "Леле мајко, машко е", и со поднаслов: "Но дали тоа навистина е толку лоша вест?" Внатре имаше многу прилози распослани на девет страници за воспитување на момчињата. Во некои се коментираа неодамнешните истражувања според кои девојчињата постигнуваат успеси на училиште, а момчињата заостануваат; во други се сугерираше дека е лесно да се воспитуваат девојчињата, момчињата прават неволи. За момчето, нѐ учи прилогот, е поверојатно дека "ќе е неуспешно на училиште, дека ќе ја изгуби работата, дека ќе доживее сообраќајна незгода, дека ќе биде насилно или ќе биде жртва на насилство" отколку девојчето. Сепак, истиот прилог заклучува дека "можеме многу да сториме за да ја смениме иднината. А на крајот, малкумина од нас ке сакаат да го сменат Хари. Vive la differance $и$ да им посакаме срека на момчињата". Нил Спенсер: "Неволите со момчињата" во The Sunday Observer Magazine (20 јуни, 1999):15. Тука оптимизмот е и збунувачки и вознемирувачки - неволата со момчињата, откриваме, всушност не е проблем својствен на машките со општествена моќ, туку е проблем на начините на постапување со децата. Иако сум охрабрена од тоа дека англискиот печат забележува дека има некакви неволи со момчињата, мислам дека стремежот да се бараат терапевтски, наместо политички решенија треба да биде смирен со други јавни дискурси што сакаат да ги преобликуваат доминантните мажествености

${ }^{3}$ Gail Bederman, Manliness and Civilization (Chicago: Chicago UP, 1995)

${ }^{4}$ Mrinalinhi Sinha, Colonial Masculinity: The "Manly Englishman" and the "Effemenate Bengali" in the Late Nineteeth Century (Manchester and New York: Manchester University Press, 1995):7.

\section{NOTES}

'Lisa Lowe has written about the relationship between dominant and minority cultures as "unstable and unclosed." In an extremely useful articulation of the dynamic motion of hegemony, Lowe writes: "We might say that hegemony is not only the political process by which a particular group constitutes itself as "the one" or "the majority" in relation to which "minorities" are defined and know themselves to be "other," but it is equally the process by which various and incommensurable positions of otherness may ally and constitute a new majority, a counterhegemony." Lisa Lowe, Immigrant Acts: On Asian American Cultural Politics (Durham, NC: Duke UP, 1996): 69.

${ }^{2}$ On a trip to London in the Summer of 1999, I was surprised to find the newspapers full of articles about an apparent full-fledged crisis in masculinity. The Sunday Observer Magazine for example featured on its cover a picture of a naked male baby with the caption: "On dear - it's a boy," and a subtitle: "But is that really such bad news?" Inside there were numerous articles in a nine page special spread about bringing up boys. Some commented on recent surveys which show girls excelling at school and boys lagging behind; others suggested that girls were easy children to raise, boys meant trouble. A boy, we learned from the lead article, was more likely "to fail at school or to lose his job, more likely to have an accident, more likely to be violent or to be the victim of violence than a girl." However, this same article concluded, "there's a lot we can do to change this future. And in the end few of us would want to change Harry. Vive la difference, and thank heaven...for little boys." Neil Spencer, "The Trouble With Boys" in The Sunday Observer Magazine (June 20,1999): 15. The optimism here is both puzzling and disturbing the trouble with boys, we discover, is not really a problem inherent to maleness of social power, rather it is a problem with the ways boys are treated. While I am heartened by the fact that the English press notes that there is some trouble with boys, I think that the tendency to seek therapeutic rather than political solutions needs to be tempered by other popular discourses which seek to refashion dominant masculinities. UP, 1995):

${ }^{3}$ Gail Bederman, Manliness and Civilization (Chicago: Chicago

${ }^{4}$ Mrinalinhi Sinha, Colonial Masculinity: The 'Manly Englishman' and the 'Effeminate Bengali' in the Late Nineteenth Century (Manchester and New York: Manchester University Press, 1995): 7.

${ }^{5}$ Sinha, for example, focuses upon formulations of masculinity that emerge out of legal controversies in British India at the end of the nineteenth century such as the libert Bill Controversy. The llbert Bill tried to give native officials some kind of criminal jurisdiction over European British subjects in India, and was met with great resistance from British colonials living in India. 
${ }^{5}$ Сина, на пример, се фокусира врз формулациите за мажественоста што се појавуваат поради легалните контроверзи во Британска Индија кон крајот на деветнаесеттиот век, каква што е контоверзноста во врска со Илберт Бил. Илберт Бил се обидел на локалните власти да им даде некој вид криминалистичка јурисдикција врз Британците во Индија, па се соочил со голем отпор од британските колонијалисти што живееле во Индија.

6 Seth Koven, "Boy Life, National Culture and Social Reform," in Nationalisms and Sexuality, ed. Andrew Parker (New York: Rotledge, 199?).

7 T.S. Eliot, "The Hollow Men" in The Complete Poems of T.C.Eliot

B Rosemary Marangoly George, The Politics of Home: Postcolonial Relocations and Twentieth Century Fiction (Cambridge: Cambridge University Press, 1996): 93. Мојата дискусија за односите меѓу модернизмот и империјалните мажествености се должи на Џорџиното поглавје за "Големата англиска традиција: Џозеф Конрад пишува до дома": 65-99.

9 Овој особено продуктивен квалитет на Конрадовите текстови ги прави податливи за продолженија и адаптации. Џорџ зборува за Остатоците на денот на Казуо Ишигуро како за исклучителна преработка на Срцето на темнината, а за Куката на Г-н Бисвас на В.С. Нејпол како за прераскажување на Алмајеровата лудост.

10 Цитирано според Ро6 Никсон во Лондон повикува. Никсон се заложува за поочигледните читања на Конрад како писател кој го овозможил ширењето на колонијалната култура.

"Joseph Konrad, The heart of Darkness [1896], (New York: Penguin, 19??):18.

12 Bill Bulford, Among the Thugs (New York: Vintage, 1991):12. Бафорд го цитира прирачникот на лордот Баден-Пауел Извидништво за момчињата (1908)

13 T.S.Eliot, "Little Gidding" from Four Quarters (1943), (New York and London: Harcourt Brace and Company, 1971): 50. И благодарам на Ли Едермен што ми укажа на врската меѓ Бафордовиот пасус и Елиотовата песна.

14 Parama Roy, "Discovering India, Imagining Thugee" in Indian Traffic (Berkeley and Los Angeles: University of California Press, 1998?).

15 Philip Meadows Taylor, Confessions of a Thug (18??). (Oxford: Oxford University Press, 19??)

16 Архивата за фудбалскиот силеџија/несмасен пивопиец е голема. Некои репрезентативни примероци на литературата вклучуваат: The Roots of Soccer Hooliganism: An Historical and Sociological Study, Eric Dunning, Patrick Murphy and John Williams (London and New York: 1988); J.A. Harrington, Soccer Hoologanism (Bristol: John Wright, 1968); Game Without Frontiers: Football, Identity and Mo-
6 Seth Koven, "Boy Life, National Culture and Social Reform," in Nationalisms and Sexuality, ed. Andrew Parker (New York: Routledge, 199?):

Eliot

7 T.S. Eliot, "The Hollow Men" in The Complete Poems of T.S.

- Rosemary Marangoly George, The Politics of Home: Postcolonial Relocations and Twentieth Century Fiction (Cambridge: Cambridge University Press, 1996): 93. My discussion of the relations between modernism and imperialist masculinities is indebted to George's chapter on "The Great English tradition: Joseph Conrad writes Home": 65-99.

9 This peculiarly generative quality to Conrad's texts makes them suitable for sequels and adaptations. George discusses Kazuo Ishiguro's The Remains of the Day as one remarkable remake of Heart of Darkness, and V.S. Naipaul's A House for Mr. Biswas as a retelling of Almayer's Folly.

${ }^{10}$ As quoted by Rob Nixon in London Calling. Nixon argues for the more obvious reading of Conrad as a writer who enables the disseminations of colonial culture.

"Joseph Conrad, The Heart of Darkness [1896], (New York: Penguin, 19??): 18.

12 Bill Buford, Among the Thugs (New York: Vintage, 1991): 12. Buford cites Lord Baden-Powell's manual, Scouting for Boys (1908).

13 T.S. Eliot, "Little Gidding" from Four Quartets (1943), (New York and London: Harcourt Brace and Company, 1971): 50. Thanks to Lee Edelman for pointing me to the connection between Buford's passage and Eliot's poem.

14 Parama Roy, "Discovering India, Imagining Thuggee" in Indian Traffic (Berkeley and Los Angeles: University of California Press, 1998?):

15 Philip Meadows Taylor, Confessions of a Thug (18??). (Oxford: Oxford University Press, 19??).

${ }^{16}$ The soccer thug/lager lout archive is vast. Some representative samples of the literature include: The Roots of Soccer Hooliganism: An Historical and Sociological Study, Eric Dunning, Patrick Murphy and John Williams (London and New York: 1988); J.A. Harrington, Soccer Hooliganism (Bristol: John Wright, 1968); Game Without Frontiers: Football, Identity and Modernity, eds. Richard Giulianotti, John Williams, (Aldershot, Hants: Arena Press, 1994); L. Allison (ed.), The Politics of Sport (Manchester: Manchester University Press, 1986); V. Duke, "The Sociology of Football: A Research Agenda for the 1990's," The Sociological Review. Vol. 39, no. 3 (August 1991); S. Redhead, Football With Attitude (Manchester: Wordsmith Press, 1991); J. Hargreaves (ed.) Sport, Culture and Ideology (London: Routledge, 1982).

17 Philip Brian Harper, Are We Not Men: The Cultural Politics of African American Masculinity (Oxford: Oxford University Press, 1996): x. 
dernity, eds. Richard Guillianotti, John Williams, (Aldershot, Hants: Arena Press, 1994); L. Allison (ed.) The Pollitics of Sport (Manchester: Manchester University Press, 1986); V. Duke "The Sociology of Football: A Research Agenda for the 1990's," The Sociological Rewiew. Vol.39, no.3 (August 1991); S. Redhead, Football With Attitude (Manchester: Wordsmith Press, 1991); J. Hargreaves (ed.) Sport, Culture and Ideology (London: Routlegde, 1982).

${ }_{17}$ Philip Brian Harper, Are We Not Men: The Cultural Politics of African American Masculinity (Oxford University Press, 1996):x.

${ }^{18}$ Irvine Welch, Trainspotting (Lonfon and New York: Norton, 1996).

19 Lisa Lowe, Immigrant Acts: 108. Очигледно е дека тука Лоу зборува за азиско-американските текстови и за нивната многу специфична врска со историјата на американскиот империјализм во Азија. Сепак, "деколонизираното пишување" секако може да примени како објаснувачки поим во текст како Возовите минуваат кој со другите текстови го дели "повеќеслојниот и повеќецентричниот напад врз... специфичните форми на колонијално владеење."

${ }^{20}$ Michel Foucault, "Of Other Spaces," trans. Jay Miskowiec, Diacritics 16, no,1 (Spring 1986): 22-27.

21 Гробиштата се еден од основните Фукоови примери за хетеротопски простор, бидејќи со текот на времето се трансформирале од тоа да бидат место за да се слави црквата во место што го чува споменот за индивидуата, до место поврзано со 6олести. Во исто време, гробиштата од тоа да бидат блиску до црквата се преместиле во урбаните предградија. Другите хетеротопски места ги вклучуваат и: театарот, киното, градината, игралиштата, мотелите, бродовите, борделите, забавните паркови, трговските центри и најважните за мојата сегашна цел: возовите.

${ }^{22}$ Sigmund Freud, "Infantile Sexuality" in Tree Essays on the Theory of Sexuality, trans. James Strachey, intro. Steven Marcus (New York: Basic Books):68.

${ }^{23}$ Види Susan Jeffords, Hard Bodies: Hollywood Masculinity in the Reagan Era (New Brunswick, NJ: Rutgers UP, 1994)
18 Irvine Welch, Trainspotting (London and New York: Norton, 1996).

${ }^{19}$ Lisa Lowe, Immigrant Acts: 108. Obviously Lowe is discussing Asian American texts here and their very specific relations to the history of U.S. imperialism in Asia. However, "decolonized writing" can certainly apply as an explanatory term to a text like Trainspotting which shares with these other texts a "multileveled and multicentered assault on...specific forms of colonial rule."

${ }^{20}$ Michel Foucault, "Of Other Spaces," trans. Jay Miskowiec, Diacritics 16, no. 1 (Spring 1986): 22-27.

${ }^{21}$ The cemetery is one of Foucault's prime examples of heterotopic space since it is transformed over time from being a place to honor the power of the church, to a place to preserve the memory of the individual, to a place associated with disease and illness; at the same time, the cemetery moves from the church side to the outskirts of urban areas. Other heterotopic sites include but are not limited to: the theater, the cinema, the garden, the fairgrounds, motels, ships, brothels, entertainment parks, malls, and most important for my purposes here: trains.

${ }^{22}$ Sigmund Freud, "Infantile Sexuality" in Three Essays on the Theory of Sexuality, trans. James Strachey, intro. Steven Marcus (New York: Basic Books): 68.

${ }^{23}$ See Susan Jeffords, Hard Bodies: Hollywood Masculinity in the Reagan Era (New Brunswick, NJ: Rutgers UP, 1994) 